Review

\title{
Lost but Not Least-Novel Insights into Progesterone Receptor Loss in Estrogen Receptor-Positive Breast Cancer
}

\author{
Michał Kunc $^{1}\left(\mathbb{D}\right.$, Marta Popęa $^{2}\left(\mathbb{D}\right.$, Wojciech Biernat $^{1}(\mathbb{D})$ and Elżbieta Senkus $^{3, *}(\mathbb{D}$ \\ 1 Department of Pathomorphology, Medical University of Gdańsk, 80-214 Gdańsk, Poland; \\ mkunc@gumed.edu.pl (M.K.); biernat@gumed.edu.pl (W.B.) \\ 2 Laboratory of Translational Oncology, Intercollegiate Faculty of Biotechnology, Medical University of Gdańsk, \\ 80-211 Gdańsk, Poland; marta.popeda@gumed.edu.pl \\ 3 Department of Oncology and Radiotherapy, Medical University of Gdańsk, 80-214 Gdańsk, Poland \\ * Correspondence: elsenkus@gumed.edu.pl; Tel.: +48-58-584-4481
}

Citation: Kunc, M.; Popeda, M.; Biernat, W.; Senkus, E. Lost but Not Least-Novel Insights into Progesterone Receptor Loss in Estrogen Receptor-Positive Breast Cancer. Cancers 2021, 13, 4755. https: / / doi.org/10.3390/ cancers13194755

Academic Editor: Luca Moscetti

Received: 23 August 2021

Accepted: 21 September 2021

Published: 23 September 2021

Publisher's Note: MDPI stays neutral with regard to jurisdictional claims in published maps and institutional affiliations.

Copyright: (c) 2021 by the authors. Licensee MDPI, Basel, Switzerland. This article is an open access article distributed under the terms and conditions of the Creative Commons Attribution (CC BY) license (https:// creativecommons.org/licenses/by/ $4.0 /)$.
Simple Summary: Most breast cancers co-express estrogen receptor $\alpha(E R \alpha)$ and progesterone receptor (PgR). These cancers are sensitive to endocrine therapy and, in general, have superior outcomes. However, a subset of tumors expresses ER $\alpha$ but loses expression of PgR in various mechanisms. The processes driving the loss of PgR may cause resistance to hormonal treatment and a more aggressive clinical course. The current review summarizes current knowledge on the biology of ER $\alpha$-positive $\operatorname{PgR}(-)$ negative breast cancer and discusses the associations between molecular mechanisms and clinical characteristics.

Abstract: Estrogen receptor $\alpha(\mathrm{ER} \alpha)$ and progesterone receptor $(\mathrm{PgR})$ are crucial prognostic and predictive biomarkers that are usually co-expressed in breast cancer (BC). However, $12-24 \%$ of BCs present $\mathrm{ER} \alpha(+) / \operatorname{PgR}(-)$ phenotype at immunohistochemical evaluation. In fact, BC may either show primary $\operatorname{PgR}(-)$ status (in chemonaïve tumor sample), lose $\mathrm{PgR}$ expression during neoadjuvant treatment, or acquire $\operatorname{PgR}(-)$ phenotype in local relapse or metastasis. The loss of PgR expression in $\operatorname{ER} \alpha(+)$ breast cancer may signify resistance to endocrine therapy and poorer outcomes. On the other hand, $\operatorname{ER} \alpha(+) / \operatorname{PgR}(-)$ BCs may have a better response to neoadjuvant chemotherapy than double-positive tumors. Loss of PgR expression may be a result of pre-transcriptional alterations (copy number loss, mutation, epigenetic modifications), decreased transcription of the PGR gene (e.g., by microRNAs), and post-translational modifications (e.g., phosphorylation, sumoylation). Various processes involved in the down-regulation of PgR have distinct consequences on the biology of cancer cells. Occasionally, negative PgR status detected by immunohistochemical analysis is paradoxically associated with enhanced transcriptional activity of $\mathrm{PgR}$ that might be inhibited by antiprogestin treatment. Identification of the mechanism of PgR loss in each patient seems challenging, yet it may provide important information on the biology of the tumor and predict its responsiveness to the therapy.

Keywords: estrogen receptor; progesterone receptor; breast cancer; treatment; microRNA

\section{Introduction}

Estrogen receptor $\alpha(\mathrm{ER} \alpha)$ and progesterone receptor $(\mathrm{PgR})$ are crucial prognostic and predictive biomarkers in breast cancer (BC). Expression of steroid hormone receptors (HRs) in cancer cells justifies the introduction of endocrine therapies (ET), e.g., selective estrogen receptor modulators (SERMs), aromatase inhibitors (AIs), or selective estrogen receptor degraders (SERDs) [1]. These therapies primarily target ER, but BCs co-expressing PgR tend to show an even better response to hormonal treatment. Since the progesterone receptor gene (PGR) is dependent on $\mathrm{ER} \alpha$, the negative PgR status may indicate altered $\mathrm{ER} \alpha$ signaling and impaired response to ET [2]. In the last two decades, the prognostic and 
predictive value of $\mathrm{PgR}$ expression has been widely disputed, with some authors postulating even to abandon PgR evaluation [3,4]. However, expression of $P G R$ is included in both the 21-gene recurrence score (Oncotype DX, Genomic Health Inc., Redwood City, CA, USA) and the 50-gene signature classifying BC into the molecular intrinsic subtypes (PAM-50) [5]. Additionally, multiple studies confirmed the usefulness of joint immunohistochemical (IHC) evaluation of ER $\alpha, \operatorname{PgR}$, human epidermal growth factor receptor 2 (HER2), and Ki67, which enables subclassification of BC into surrogate intrinsic phenotypes, with the cut-off value discriminating between luminal A-like and luminal B-like tumors proposed at $20 \%$ of cells positive for PgR expression [6]. Nevertheless, according to the American Society of Clinical Oncology/College of American Pathologists (ASCO/CAP) guidelines, in routine assessment $\mathrm{BC}$ is considered $\operatorname{PgR}(-)$ if $<1 \%$ or $0 \%$ of tumor cell nuclei are immunoreactive [7].

Single hormone receptor-positive breast cancers have two distinct categories. First, $\mathrm{ER} \alpha(-) / \operatorname{PgR}(+) \mathrm{BC}$ is extraordinarily rare and is molecularly, morphologically, and clinically similar to triple-negative breast cancer $[8,9]$. Another type, $\operatorname{ER} \alpha(+) / \operatorname{PgR}(-)$, is relatively more common, constituting approximately $12-24 \%$ of all BC cases $[10,11]$. The prognostic and predictive value of this phenotype has been thoroughly analyzed and several reviews and meta-analyses have been recently published [10,12]. In general, $\mathrm{ER} \alpha(+) / \operatorname{PgR}(-) \mathrm{BCs}$ are more often aggressive, high-grade tumors, with high proliferation index, high glucose metabolism, and outcomes inferior to double-positive tumors $[13,14]$. Nonetheless, patients with single hormone receptor-positive BC still benefit from hormonal therapy, and recent findings emphasize the importance of ET implementation in this group of patients [15].

$\mathrm{ER} \alpha(+) / \operatorname{PgR}(-)$ tumors develop more commonly in patients older than 55 years than the double-positive cases [10]. Lower estrogen levels in elderly females may contribute to lower expression of ER $\alpha$-dependent proteins, e.g., PgR [16]. Moreover, the phase of the menstrual cycle at which the tumor is excised can influence the PgR status: carcinomas removed in the luteal phase more often display $\operatorname{PgR}(-)$ phenotype, compared to the follicular phase [17]. Other risk factors for $\operatorname{ER} \alpha(+) / \operatorname{PgR}(-) B C$ development include hormone replacement therapy (combination of estrogen and synthetic progestin), alcohol consumption, and some antidepressants [18-20].

PgR expression provides independent prognostic information and increases the prognostic accuracy of ER assessment in primary BC [21]. One study reported that the presence of $\mathrm{PgR}(+)$ proliferating (Ki67-expressing) cells but not $\operatorname{PgR}(+)$ non-proliferating cells is associated with better disease-free survival [22].

However, no effect of PgR expression on the benefit from tamoxifen use was demonstrated in the meta-analysis of 20 trials involving more than 21 thousand early BC patients [23]. In metastatic $\mathrm{ER}(+)$ disease, $\mathrm{PgR}$ expression is associated with an increased probability of response to tamoxifen, longer time to treatment failure, and longer overall survival [24]. No difference was seen, however, in the magnitude of benefits from the addition of cyclindependent kinases 4 and 6 (CDK4/6) inhibitor to ET for advanced BC treatment [25].

On the other hand, PgR-negativity in $\mathrm{ER} \alpha(+) \mathrm{BC}$ is associated with higher rates of pathological complete response to neoadjuvant chemotherapy (NAC) when compared to double-positive BC [26-28]. Thus, PgR status may be of great importance in predicting response to NAC in $\mathrm{ER} \alpha(+)$ patients.

Moreover, $\mathrm{PgR}$ is a predictive factor (as depletion of $\mathrm{PgR}$ correlates with poor response to megestrol acetate in advanced $\mathrm{BC}$ ) and a potential target for personalized therapy in $\mathrm{BC}$, either with the use of antiprogestins or, surprisingly, progestogens [29].

While the epidemiology and clinical behavior of this type of single hormone receptorpositive $\mathrm{BC}$ is well described, the underlying biology of these tumors remains obscure. In 2005 a comprehensive description of the biology of PgR loss in $\mathrm{ER} \alpha(+) \mathrm{BC}$ was published by Cui et al. [30]. The current paper aims to provide an update on this subject, focusing on the studies published in the last 15 years. A special emphasis is put on the novel 
mechanisms of PgR loss, genetic landscape and biology of $\mathrm{ER} \alpha(+) / \operatorname{PgR}(-)$ tumors, and the role of microRNA (miRNA) in the down-regulation of PgR.

\section{Mechanisms of PgR Negativity}

$\mathrm{BC}$ may either show primary PgR negative phenotype (i.e., negative PgR expression in tumor sample assessed before systemic therapy), lose PgR expression during neoadjuvant treatment (assessed in the postsurgical specimen), or acquire PgR negative phenotype in local relapse or metastasis.

\subsection{Loss of PgR at the Genetic Level}

Among the HER2(-) group of tumors, the $\mathrm{ER} \alpha(+) / \operatorname{PgR}(-)$ cases show significantly lower $P G R$ mRNA expression when compared to $\mathrm{ER}(+) / \operatorname{PgR}(+)$ cancers, suggesting that in most cases the loss of $\mathrm{PgR}$ occurs before or during transcription [31]. At the genetic level, PgR loss might be explained by a copy number loss of the PGR gene, which was reported to occur in $27-52 \%$ of cases of BC [31]. Importantly, exogenous expression of $\mathrm{PgR}$ in breast cancer cells ensued growth inhibition in an MCF-7 cell line with a heterozygous loss of the $P G R$ gene [32].

On the other hand, PGR mutations are exceedingly rare, since in the analysis of $959 \mathrm{ER}(+) / \operatorname{PgR}(-)$ cases all the tumors were classified as PGR-wild-type [33]. In another large dataset, only 9 missense mutations in the $P G R$ gene were identified (estimated frequency $0.36 \%$ ) [34]. A recent study on $P G R$ variants in metastatic $E R(+) B C$ demonstrated that 3 out of 4 samples of functionally deleterious Y890C variant were $\operatorname{PgR}(-)$ by IHC, so this specific variant may contribute to PgR loss by clonal selection [35].

\subsection{The Interplay between Growth Factors and PgR Expression}

The role of growth factors and growth factors receptors in the pathogenesis of $\mathrm{ER} \alpha(+) / \operatorname{PgR}(-)$ tumors has been postulated for many years [30]. Insulin-like growth factor (IGF), epidermal growth factor (EGF), and heregulin activate signaling pathways downregulating PgR expression [30]. Accordingly, $\mathrm{ER} \alpha(+) / \operatorname{PgR}(-) \mathrm{BC}$ s demonstrate an increased frequency of epidermal growth factor receptor (EGFR) and HER2 overexpression [30]. In normal circumstances, ER $\alpha$ mainly exerts genomic effects but in the case of enhanced growth factor stimulation, membrane-initiated steroid signaling (MISS) starts to predominate [26]. This transition ensues PgR down-regulation by its phosphorylation via extracellular signalregulated protein kinase (ERK1/2), phosphatidylinositol 3-kinase (PI3K), Akt, and mammalian target of rapamycin complex 1 (mTORC1) (Figure 1). Importantly, SERMs can stimulate MISS, which partially explains the greater benefits of $\operatorname{ER} \alpha(+) / \operatorname{PgR}(-)$ patients from AIs treatment compared to tamoxifen [30,36].

Additional proofs of the role of growth factors in the development of $\operatorname{ER} \alpha(+) / \operatorname{PgR}(-)$ BC come from a neu-related lipocalin-transforming growth factor $\alpha$ (NRL-TGF $\alpha$ ) transgenic mouse model [37]. During tumorigenesis, ER $\alpha$ expression was noted in all types of precursor lesions and persisted in cancer, whereas PgR expression was lost very early. In bi-transgenic mice overexpressing prolactin (PRL) and TGF $\alpha$ (NRL-PRL/TGF $\alpha$ ), these hormones cooperatively enhance Akt activity, resulting in decreased PgR and increased ER $\alpha$ expression [38]. Despite enhanced ER $\alpha$ expression, the developed tumors were insensitive to estrogens, again supporting the hypothesis on diminished hormone responsiveness in $\mathrm{ER} \alpha(+) / \operatorname{PgR}(-) \mathrm{BC}$. Thus, targeting growth factors pathways may increase sensitivity to ET in single hormone receptor-positive BC. 


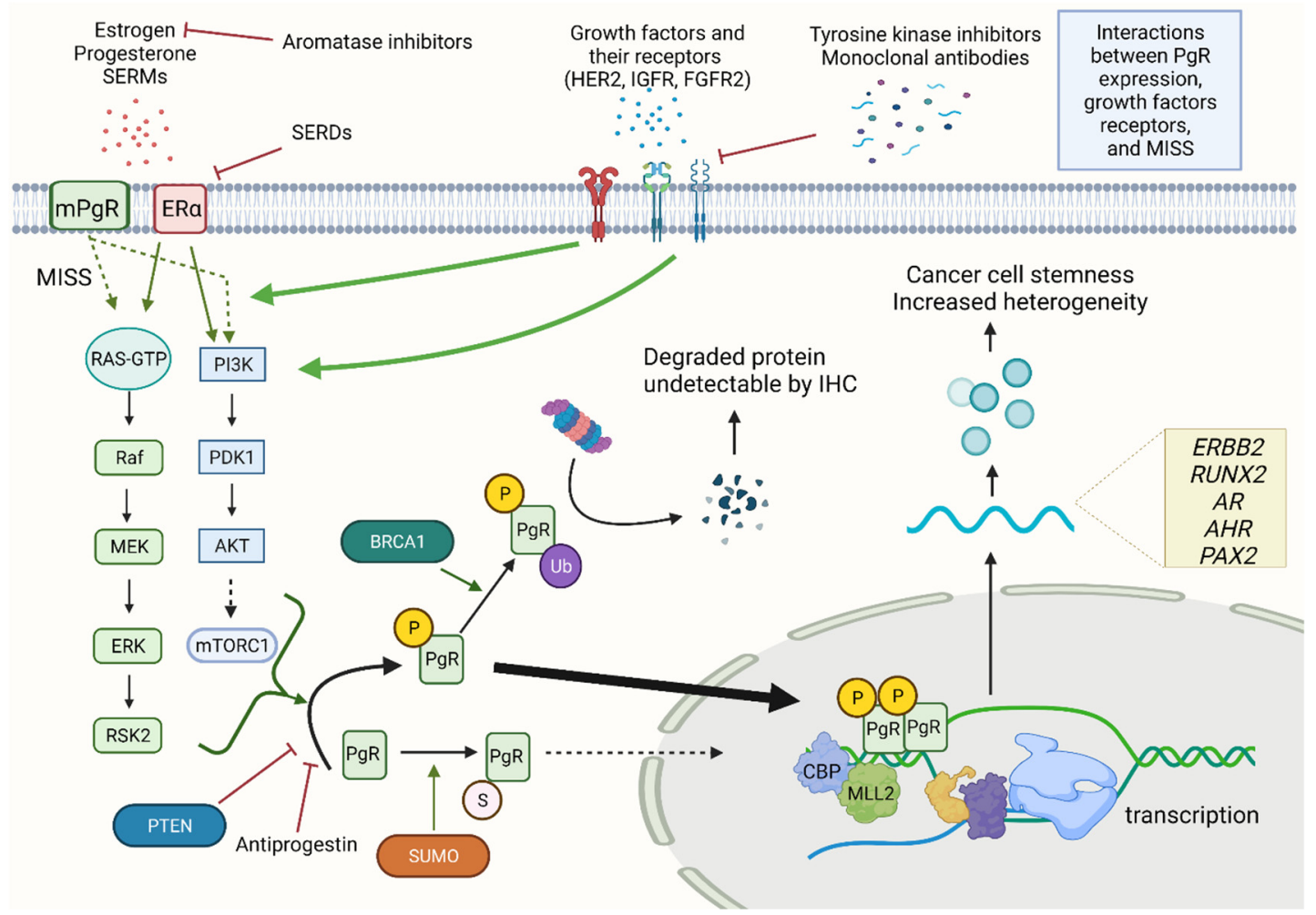

Figure 1. Interactions between PgR, growth factor-dependent signaling and MISS Green arrows demonstrate stimulatory effects, red T-shaped lines depict inhibition. Overactive growth factors receptors stimulate MISS and directly activate various signaling pathways leading to activation of multiple kinases, i.e., ERK, AKT, RSK2, mTORC1, which phosphorylate PgR at Ser294. Phosphorylated PgR is undersumoylated, undergoes rapid ubiquitination and degradation in proteasomes reflected by $\mathrm{PgR}(-)$ status in immunohistochemistry. Phosphorylated PgR is also transcriptionally overactive, recruits CBP and MLL2, and enhances transcription of genes involved in cancer progression. Abbreviations: AHR-aryl hydrocarbon receptor; AKT—protein kinase B; AR—androgen receptor; BRCA1—Breast cancer type 1 susceptibility protein; CBP-CREB-binding protein; ER $\alpha$ - estrogen receptor $\alpha$; ERBB2-Erb-B2 Receptor Tyrosine Kinase 2; ERK-extracellular-regulated kinase; FGFR2-fibroblast growth factor receptor 2; HER2-human epidermal growth factor receptor 2; IGFR-insulin-like growth factor receptor; IHC—immunohistochemistry; MEK—-mitogen-activated protein kinase; MISS—membrane-initiated steroid signaling; MLL2-mixed linage leukemia gene 2; mTORC1-mammalian target of rapamycin complex 1; P—phosphate residues; (m)PgR-(membranous) progesterone receptor; PAX2 - paired box 2; Raf-rapidly accelerated fibrosarcoma; PDK1-3-phosphoinositide-dependent protein kinase-1; PI3K-phosphoinositide 3-kinase; PTEN-phosphatase and tensin homolog; RAS—rat sarcoma virus; RSK2 - ribosomal S6 kinase 2; RUNX2—RUNX Family Transcription Factor 2; SERDs—selective estrogen receptor degraders; SERMs—-selective estrogen receptor modulators; Ub-ubiquitin. Created with BioRender.com—accessed date 22 September 2021.

\subsection{Molecular Mechanisms Underlying False-Negative PgR Staining in IHC}

Progesterone receptor undergoes multiple post-translational modifications, including phosphorylation, acetylation, sumoylation, methylation, and ubiquitination [39]. Even in the absence of ligands, PgR is constitutively phosphorylated at some sites, and exposure to progestogen results in a net increase in the phosphorylation [40]. The result of this modification depends on a specific phosphorylation site that modulates PgR stability, nuclear transport, DNA binding, and transcriptional activity. Hormone binding results in poly-ubiquitination of $\mathrm{PgR}$ leading to ligand-induced $\mathrm{PgR}$ down-regulation - this process is paradoxically the hallmark of cells actively expressing PgR-dependent genes [40]. In human BC cells, ERK1/2 activation triggers PgR-B phosphorylation at Ser294, which, thereby, inhibits PgR sumoylation at Lys388. Undersumoylated $\operatorname{PgR}(-) \mathrm{B}$ is derepressed and transcriptionally overactive, thus highly sensitive to low progestin concentration [41] 
(Figure 1). However, Ser294 phosphorylation targets the receptors for rapid proteasomal degradation [42]. Moreover, PgR Ser294 and Ser400 phosphorylation reduce PgR nuclear export, probably enhancing the genomic action of progesterone [43], and phosphorylationinduced PgR desumoylation enhances the transcription of proliferative genes via recruitment of a CREB-binding protein (CBP) and mixed linage leukemia gene 2 (MLL2) [44]. Thus, in the final effect, PgR might express enhanced transcriptional activity but, simultaneously, undergo instant degradation and be undetectable by IHC [42]. An animal study by Zhang et al. demonstrated that the loss of tumor suppressor, Tat-Interacting Protein (Tip30), accelerates cancerogenesis in the MMTV-Neu mouse model of BC, and leads to the development of exclusively ER(+)/PgR(-) tumors [45]. Loss of Tip30 results in impaired degradation of EGFR and enhanced Akt signaling, which correlated with both increased expression and phosphorylation of ER $\alpha$ and loss of PgR in IHC staining [45]. In in vitro culture, the PgR protein was detectable following proteasome inhibition, and the progesterone antagonist RU486 suppressed the growth of Neu+/Tip30-/ - tumors [45].

Finally, various clones of anti-ER and anti-PgR antibodies may show discordant results, and multiple additional pre-analytic or analytic factors influence the final quantification of steroid hormones expression. Failure to detect PgR expression by IHC occurs in various laboratories with a frequency of 5 to $15 \%$ of cases [46]. While PgR-negativity assessed by IHC may be a technical issue, the other possibility is that alternative splicing of PgR produces cancer-specific variants of PgR that are undetectable with N-terminally targeting antibodies. These truncated variants are generated by the deletion of some of the eight exons of $P G R$ or by the preservation of introns and are capable of binding to progesterone, interacting with co-factors, and binding to DNA, thus they may remain functional [47]. Nevertheless, the clinical significance of alternative splicing of PgR needs to be elucidated. Identification of patients with false-negative PgR status may help to identify patients who are more likely to benefit from ET.

\subsection{Influence of Tumor Suppressors Loss on PgR Expression}

The phosphatase and tensin homolog (PTEN) is a tumor suppressor frequently lost in BC [48]. The role of PTEN is to dephosphorylate phosphatidylinositol 3,4,5-triphosphate (PIP3), thus the loss of PTEN correlates with higher levels of PIP3, which, in turn, activates the Akt signaling pathway [48]. Loss of heterozygosity at the PTEN locus coexisting with HER2 overexpression results in substantial Akt activation, leading to loss of PgR [49] (Figure 1). Additionally, PTEN-knockout mice (K8PTEN-KO) demonstrate increased proliferation of mammary epithelial cells mainly restricted to the preferential expansion of $\operatorname{PgR}(-)$ cells [50].

In contrast to PTEN, the association between Breast cancer type 1 susceptibility protein (BRCA1) and PgR expression is ambiguous. On the one hand, BRCA1 was reported to stimulate the ubiquitination of $\mathrm{PgR}$ protein by $\mathrm{E} 2$ enzyme $\mathrm{UbcH} 5 \mathrm{c}$ and its subsequent degradation [51]. On the other hand, Sanford et al. found no difference in the proportion of low-positive ( $<10 \%$ positive cells) and negative PgR staining between patients with and without deleterious germline BRCA1 mutations [52].

\subsection{Epigenetic Mechanisms of PgR Suppression}

DNA methylation is the most important epigenetic mechanism orchestrating transcription. The first report on the inverse association between PGR promoter methylation and PgR expression in BC was published in 1996 and since then this observation has been confirmed by several studies [53]. Recent data demonstrate that IHC PgR(-) tumors show higher PGR methylation [54-57]. Nonetheless, in PgR(-) breast tumors, PGR methylation is usually either low or absent, so hypermethylation of $P G R$ promoter is unlikely the major mechanism of PgR silencing, albeit some data are contradictory [56-58]. Interestingly, one study reported a higher incidence of DNA methylation in PGR promoter in HER2-amplified/overexpressing cases, pointing to the role of methylation in the pathogenesis of $\operatorname{ER}(+) / \operatorname{PgR}(-) / \operatorname{HER} 2(+)$ breast tumors [59]. 
Several studies point to an association between PGR methylation and patients' outcome, e.g., tamoxifen resistance [57,60]. Additionally, long-term tamoxifen treatment leads to epigenetic silencing of ER-responsive genes, including PGR [61]. Owing to a high prevalence of $\mathrm{ER}(+) \operatorname{PgR}(-)$ phenotype among breast tumors recurring after tamoxifen treatment, $P G R$ methylation status was proposed as a predictive marker for tamoxifen insensitivity [61]. Consequently, loss of PgR was also demonstrated in BC cell lines with decreased tamoxifen sensitivity following long-term treatment [62]. Moreover, in MCF-7 $\mathrm{BC}$ cell line signaling from membrane-associated ER contributes to epigenetic modulation of $P G R$ gene via the action of histone methyltransferase enhancer of Zeste homolog 2-EZH2 [63].

Numerous groups have reported on the restoration of $P G R$ gene expression in $\operatorname{PgR}(-)$ cell lines following treatment with agents blocking DNA epigenetic modifications, namely the inhibitors of histone deacetylases and DNA methyltransferases [64,65]. Exposure to epigenetic modulators also resulted in increased PGR mRNA expression in the hormonereceptor-positive MCF-7 cell line [64]. In the future, it may be possible to convert $\operatorname{PgR}(-)$ $\mathrm{BC}$ into $\operatorname{PgR}(+)$ with the use of epigenetic modulators in order to enhance its sensitivity to ET [66].

\subsection{The Interplay between Isoforms and Splice Variants of Steroid Hormone Receptors and $P g R$ Expression}

Whereas most estrogenic actions in $\mathrm{BC}$ cells seem to be driven by ligand binding to $\mathrm{ER} \alpha$ homodimers, the latter may also form heterodimers with ER $\beta 1$, which can promote transcription of a distinct pool of genes, and to down-regulate several ER $\alpha$-dependent genes, including PGR (Figure 2) $[67,68]$. The inverse correlation between ER $\beta c x$, a splice variant of $E R \beta$, and PgR was noted; interestingly PgR-low BCs expressing ER $\beta c x$ showed poorer response to tamoxifen [69].

Expression of $\mathrm{PgR}$ is also modulated by splice variants of $\mathrm{ER} \alpha$, e.g., ER $\alpha 36$, which positively correlates with PgR expression [70,71]. In vitro study utilizing ER $\alpha 36$ knock-out cell lines demonstrated reduced levels of $\mathrm{PgR}$ and its altered phosphorylation at Ser294 and Ser345 [71].

Additionally, there is a dominant-negative splice variant of $\operatorname{ER} \alpha(E R \alpha \Delta 7)$, which is non-functional, but is detected by IHC. This may explain why a subset of ER $\alpha(+)$ tumors shows the molecular characteristics of the basal subtype [72]. Interestingly, the frequency of $\operatorname{PgR}$ expression in $\mathrm{ER} \alpha(+) / \mathrm{ER} \alpha \Delta 7$-high basal carcinomas was $29.7 \%$ compared to $85.2 \%$ for $E R \alpha(+) / E R \alpha \Delta 7$-low luminal B carcinomas [73]. Identification of such hormone receptor variants may in the future support treatment decision-making, but current routine procedures have not incorporated their assessment yet.

\subsection{MicroRNA (miRNA) Profiles of $E R \alpha(+) / P g R(-)$ Breast Cancers}

miRNAs are small non-coding molecules with an average length of 22 nucleotides [74]. They regulate gene expression via the formation of miRNA-induced silencing complex (miRISC), which binds to the 3'UTR of a target gene [75]. Subsequently, translational repression, mRNA destabilization, degradation, and deadenylation occur [75].

The interplay between miRNAs and ER $\alpha$ expression is well described, but still not completely understood. Estrogens bound to ER $\alpha$ regulate miRNA processing and the formation of miRISC interacting with Drosha, DICER, and protein argonaute-2 (AGO2), and in this way influence gene repression by miRNAs [76]. On the contrary, multiple miRNAs modulate the expression and action of ER $\alpha$ via direct interactions with ESR1 mRNA and alterations of $E R \alpha$ coregulators. Additionally, some oncogenic miRNAs interfere with ER $\alpha$-dependent signaling pathways, which, in consequence, may result in partial loss of ER $\alpha$ functionality reflected by loss of PgR expression in BC (i.e., acquisition of $\mathrm{ER}(+) / \operatorname{PgR}(-)$ phenotype). 


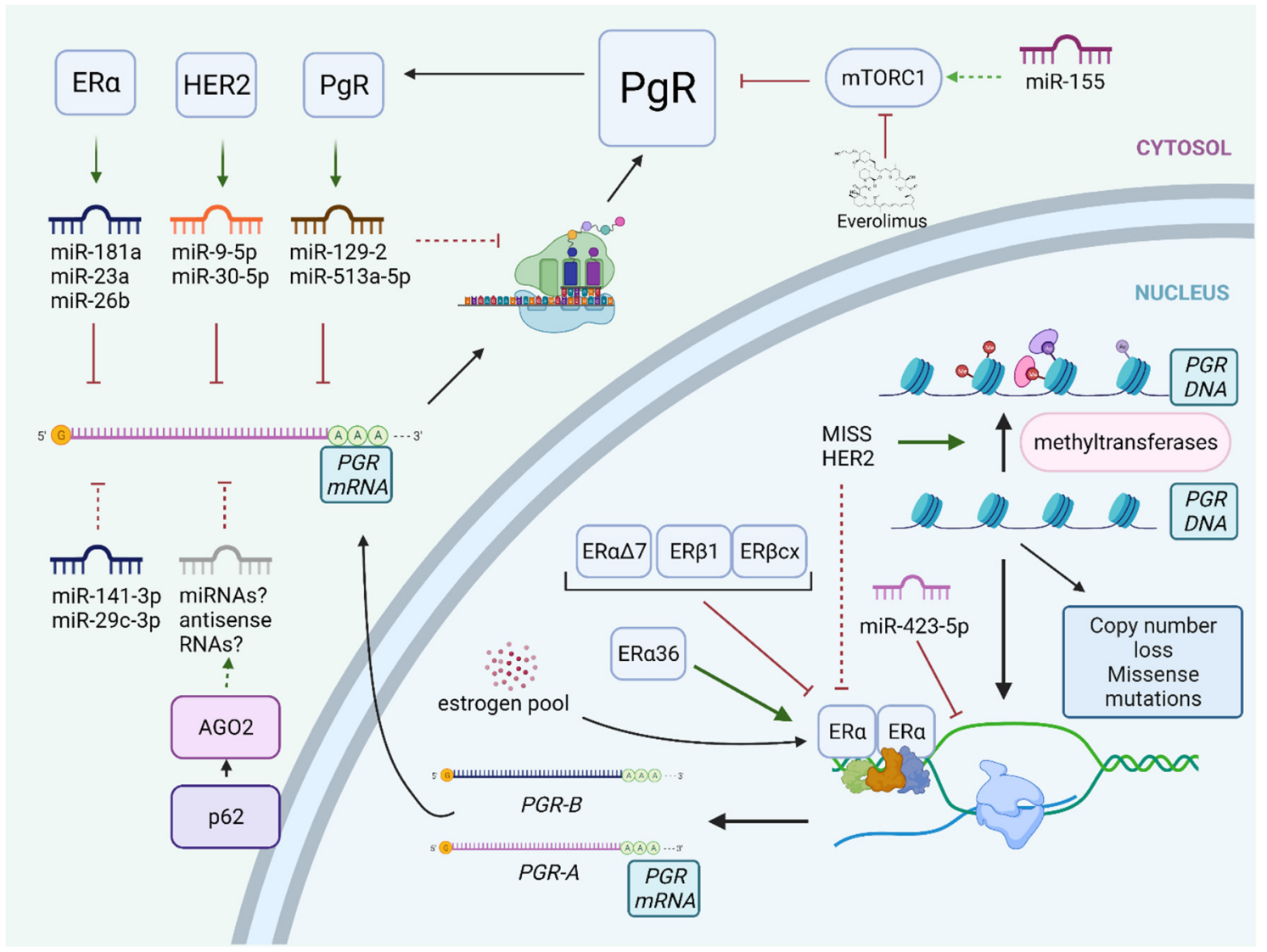

Figure 2. Pre-translational mechanisms of PgR loss and down-regulation. Green arrows indicate stimulatory effects, red T-shaped lines depict inhibitory effects, dotted lines show potential effects. At pre-transcriptional stage, PgR loss is a consequence of methylation of $P G R$ promoter, copy number loss (often), or mutations (very rarely). Splice variants of ER $\alpha$ and ER $\beta$ may either suppress or activate the transcription of PGR. Low levels of estradiol after menopause are frequently insufficient to induce expression of PgR. PGR mRNA is a direct target of multiple miRNAs, but some miRNAs may down-regulate PgR indirectly, e.g., via activation of mTORC1. For details, see text. Abbreviations: AGO2-protein argonaute-2; ER $\alpha$ —estrogen receptor $\alpha$; HER2-human epidermal growth factor receptor 2; miRNAs-microRNAs; MISS - membrane-initiated steroid signaling; mTORC1—mammalian target of rapamycin complex 1; PGR - progesterone receptor gene; $\mathrm{PgR}$ - progesterone receptor. Created with BioRender.com—accessed date 22 September 2021.

Recent studies have also shed some light on miRNA regulation of PgR expression. Interestingly, the $3^{\prime} U T R$ of $P G R$ is the longest amongst mRNAs encoding steroid receptors (9434 nucleotides) but surprisingly contains only six conserved miRNA binding sites. It was demonstrated that exogenous miR-423-5p is capable of inhibiting PGR gene transcription in vitro [77], miR-126-3p suppresses PgR expression in mouse mammary gland [78], and miR-181a, miR-23a, and miR-26b down-regulate $\operatorname{PgR}$ in $\operatorname{ER} \alpha(+) B C[79,80]$. $\mathrm{miR}-181 \mathrm{a}$ and $\mathrm{miR}-26$ are repressed by estrogen and they belong to the feed-forward loop involving ER $\alpha$. Their down-regulation following estrogenic stimulation leads to $P G R$ up-regulation and their up-regulation in $\operatorname{ER} \alpha(+)$ tumors may contribute to $\operatorname{ER} \alpha(+) / \operatorname{PgR}(-)$ $\mathrm{BC}$ development [79]. The main interactions between microRNAs and PgR expression are shown in Figure 2.

Estrogen-dependent PgR up-regulation may be abrogated by progestin-controlled miRNAs, most notably miR-129-2 and miR-513a-5p. Progesterone treatment of BC cell lines leads to the up-regulation of miR-129-2, resulting in down-regulation of $\mathrm{PgR}$, and tumors with elevated miR-129-2 have significantly decreased levels of PgR [81]. Similar effects were observed for miR-513a-5p, which represses PgR expression and reduces the amounts of PgR induced by estrogenic stimulation [82]. In vitro studies demonstrate that inhibitors 
of miR-129-2 increase expression of PgR providing a potential tool for stabilization of PgR levels in PgR-low/negative patients considered for hormonal therapy [81].

In our recent study, we compared miRNA profiles of two groups of single-steroidhormone-receptor-positive $\mathrm{BC}, \mathrm{ER}(+) / \operatorname{PgR}(-)$ and $\mathrm{ER}(-) / \operatorname{PgR}(+)$ [83]. The first group demonstrated elevated levels of miR-30a-5p, miR-29c-3p, miR-141-3p-members of miRNA clusters characterizing ER(+) tumors, and miR-423-5p, whose role in PgR silencing was discussed before [77]. Interestingly, miR-30-5p has previously been shown to suppress $\mathrm{PgR}$ expression in $\mathrm{BC}$ cell lines [83]. Additionally, the miR-29 family targets and represses transcription of the PgR-regulated gene, ATP1B1 [82]. Conversely, progestin treatment inhibits the expression of miR-29. miR-141-3p is another miRNA with reciprocal associations with PgR: down-regulation of miR-141-3p increases PgR levels, whereas progestin treatment decreases levels of miR-141-3p [84]. In conclusion, miR-29 and miR-141-3p up-regulation in $\mathrm{ER}(+) / \operatorname{PgR}(-) \mathrm{BC}$ may reflect diminished progestin-dependent signaling in these tumors.

An interesting mechanism of $\mathrm{PgR}$ regulation in $\mathrm{BC}$, partially driven by miRNA, involves a model, in which early lesions recapitulate the developmental program of normal mammary gland orchestrated by progesterone signaling via PgR and moderate HER2 expression [85]. This program facilitates the early dissemination of cancer cells, enhancing migration and stemness. Growing lesions gradually increase their tumor cell density and overexpress HER2, which up-regulates the expression of miR-9-5p and miR-30a-5p, leading to the down-regulation of $P G R$ in the mouse BC model. This mechanism increases the proliferation of cells contributing to primary tumor growth but impairs its ability to spread. Plausibly, ER $\alpha(+) / \operatorname{PgR}(-) / \mathrm{HER} 2(+)$ BCs show inferior prognosis because they represent an end-point in the pathway beginning with early, occult dissemination initially driven by $\operatorname{PgR}(+)$ cells, while clinically overt $\operatorname{PgR}(-)$ cancers may comprise only of residual scattered phospho-PgR(+) spots with stem cell potential and an ability to spread [85].

An additional mechanism of PgR regulation by miRNA involves miR-155 and the mTOR pathway. In BC, IGF-mediated mTORC1 activation down-regulates PgR expression [30]. Increased expression of miR-155 in ER $\alpha(+)$ BC cells enhances mTORC1 signaling via inhibition of the mTORC2 signaling component Rictor [86]. TCGA data on BC show that levels of Rictor and PgR positively correlate with each other, whereas Raptor (complexed with mTORC1) shows an inverse correlation with PgR [86]. mTOR inhibitor, everolimus, demonstrated efficacy in combination with ET in advanced BC and is generally believed to reverse endocrine resistance by inhibition of mTORC-1-dependent phosphorylation of $\mathrm{ER} \alpha$, but de-repression of PgR expression may represent another possible mechanism of action [87-89]. Nevertheless, limited data suggest that PgR status is not a predictive factor in advanced/metastatic BC treated with everolimus [90].

Curiously, a group of small duplex RNAs, antigene RNAs (agRNAs) are also able to regulate gene expression by targeting gene promoters (noncoding transcripts). Several studies demonstrated that PgR expression is regulated by synthetic agRNAs mediated by argonaute (AGO) proteins, but it was unknown if similar effects may be mediated by endogenous RNAs [91]. A very recent study shows that sequestosome 1 (p62) accumulation in $\mathrm{BC}$ cells triggers $\mathrm{PgR}$ suppression in an AGO2-mediated mechanism, comprising most likely agRNAs, not miRNAs [92]. On the contrary, in another study, high AGO2 levels were correlated with PgR loss due to altered ER $\alpha$ signaling probably driven by miRNA [93]. If small RNAs can precisely up-regulate expression PgR in BC to increase its sensitivity to ET remains to be elucidated.

\section{Loss of PgR during Therapy and in Breast Cancer Relapse}

A large meta-analysis of steroid HRs discordance in primary and recurrent BCs estimated the frequency of secondary PgR loss at $46 \%$ of patients, being more common in distant metastases than in local relapses [23]. The prognostic significance of this conversion is not well established, however, some studies report on the association between worse outcomes and the negative conversion of steroid HRs [12]. The loss of ER $\alpha$ and/or PgR in relapsing tumors or after primary systemic treatment probably indicates the selection 
of HR-negative cells in a heterogeneous pool of tumor cells. Moreover, circulating tumor cells (CTCs) frequently show discordant profiles with primary tumors. $\operatorname{PgR}(-)$ CTCs are present in $68-87 \%$ of patients with $\mathrm{PgR}(+)$ primary tumor, and this pool may be responsible for $\operatorname{ER} \alpha(+) / \operatorname{PgR}(-)$ metastases [94]. On the other hand, in metastatic BC, the loss of PgR expression on CTCs may occur, even if still present in both primary tumors and metastases [95].

The switch from $\operatorname{PgR}(+)$ to $\operatorname{PgR}(-)$ after neoadjuvant chemotherapy occurs in $12-15 \%$ of cases and is associated with worse clinical outcomes [96,97]. Similarly, neoadjuvant ET with SERMs or AIs may lead to the down-regulation of ER $\alpha$ and PgR, respectively [12]. A letrozole-induced decrease in PgR expression is most likely due to decreased estrogens levels and diminished estrogenic signaling [98,99]. Accordingly, studies on patient-derived xenografts and cell lines demonstrate that estrogen withdrawal can lead to PgR expression loss [100].

The decline in PgR expression is also promoted in a time-dependent manner by treatment with fulvestrant, as demonstrated in sequential biopsies of advanced BC [94]. Fulvestrant and the other SERDs have no agonistic activity and inhibit ligand binding to $E R \alpha$, promote its degradation, and diminish transcription of ER $\alpha$-dependent genes, including PGR [101]. Fulvestrant response rate seems independent from the baseline HER2 and PgR status because it antagonizes nuclear, cytoplasmatic, and membranebound ERs, completely inhibiting the cross-talk between the growth factor receptor and estrogen signaling [102]. Intriguingly, patients with a retained high PgR expression have a longer duration of response than patients with PgR loss at 6 weeks of treatment [101]. Moreover, overexpression of Tissue Inhibitor of Metalloproteinases-1 (TIMP1) ensues the down-regulation of PgR and drives resistance to fulvestrant in the MCF-7 cell line, but the mechanism of TIMP1-associated PgR depletion is unknown [103]. Resistance to fulvestrant may also be driven by mitogen-activated protein kinase (MAPK) pathway activation with increased levels of ERK, MEK, and RSK, kinases known to phosphorylate and inactivate PgR, hence, potentially, providing space for treatment with antiprogestins [104]. Phase 2 clinical trial investigating the combination of fulvestrant and onapristone for advanced or metastatic BC after progression on aromatase and CDK4/6 inhibitors (NCT04738292) is planned [105].

\section{Genetic Landscape of $\operatorname{ER} \alpha(+) / \operatorname{PgR}(-) \mathrm{BC}$}

Genomic alterations of $\operatorname{ER} \alpha(+) / \operatorname{PgR}(-) \mathrm{BC}$ have been extensively studied in recent years. In terms of genetic stability, these tumors are characterized by increased DNA copy number gains when compared to double-positive BC cases [16]. Their mutation burden is intermediate between double-positive and triple-negative BCs [31]. In a comprehensive analysis of the large publicly available datasets, $\operatorname{ER} \alpha(+) / \operatorname{PgR}(-)$ tumors shared 5668 mutated genes with $\mathrm{ER} \alpha(+) / \operatorname{PgR}(+)$ cancers, while 1319 genes $(19 \%)$ were uniquely altered in the former group [33]. The most commonly mutated genes were PIK3CA, TP53, GATA3, CHD1, KMT2C, MUC16, MAP3K1, ARID1A, AHNAK2, and SYNE2 [29]. When compared to double-positive cancers, $\operatorname{ER} \alpha(+) / \operatorname{PgR}(-) / \mathrm{HER} 2(-)$ tumors displayed higher TP53 and lower PIK3CA mutation rate, and more frequently showed amplification of oncogenes ZNF703 and RPS6KB1 [13,27].

Taking into consideration intrinsic molecular phenotypes, $15-46 \%$ of $\operatorname{ER} \alpha(+) / \operatorname{PgR}(-) /$ HER2(-) BCs are classified as PAM50-defined luminal A tumors, next 29-58\% are classified as luminal B, and $20-27 \%$ as HER2-enriched or basal $[31,106]$. When compared to doublepositive tumors, $\operatorname{ER} \alpha(+) / \operatorname{PgR}(-) \mathrm{BC}$ are characterized by lower endocrine sensitivity scores, enriched biosynthesis, metabolism, and DNA replication. The probability of benefits from $\mathrm{ET}$ in $\mathrm{ER} \alpha(+) / \operatorname{PgR}(-)$ tumors may be estimated also from three IHC markers: GATA3, CK5, and EGFR [31].

Analysis of mRNA expression profiles from several datasets demonstrated that $\mathrm{ER} \alpha(+) / \operatorname{PgR}(-) \mathrm{BC}$ s share gene expression patterns both with double positive and double negative tumors [107]. This was confirmed also in our analysis of the TCGA dataset, 
where we identified 2 and 32 differently expressed genes between $\mathrm{ER}(+) / \operatorname{PgR}(-)$ and double-positive or double negative tumors, respectively. Importantly, we found only 10 genes uniquely differentiating between two subtypes of single hormone receptor-positive tumors [83].

\section{The Biology of $\operatorname{ER} \alpha(+) / \operatorname{PgR}(-)$ BC}

The biology of $\mathrm{ER} \alpha(+) / \operatorname{PgR}(-) \mathrm{BC}$ cells is probably highly variable and depends on many cofactors (Figure 3). Isolated effects of ER (stimulated by estrogens) and PgR (stimulated by progestins) on gene expression are similar because they regulate the expression of shared target genes in the same direction (genomic agonism) [108]. In BC cells positive for both types of steroid hormone receptors, PgR competes with ER $\alpha$ regarding access to RNA polymerase III, and, hence, reduces its availability and ER $\alpha$-dependent translation [84]. In consequence, when PgR expression is lost, ER $\alpha$ gains access to a broader range of translational machinery, which may promote tumor aggressiveness and growth. Moreover, chromatin binding of ER $\alpha$ is more consistent in double-positive tumors, whereas $\mathrm{ER} \alpha$ binding patterns in PgR(-) subset are highly variable [108,109]. In PgR-deficient cells, $\mathrm{ER} \alpha$ predominantly binds in the proximity to transcription start sites, whereas in $\operatorname{PgR}(+)$ cells PgR redirects $\mathrm{ER} \alpha$ to bind distally to promoters. In consequence, in $\mathrm{ER} \alpha(+) / \operatorname{PgR}(-)$ $\mathrm{BC} E R \alpha$ seem to act as a proximal promoter rather than distal enhancer of gene transcription, which stimulates pro-growth estrogenic signaling and reduces the responsiveness to ET [108]. Thus, PgR acts as a molecular rheostat regulating ER activity. Additionally, PgR mediates ER $\alpha$ chromatin binding to genes involved in cell death, apoptosis, and differentiation pathways and blocks ER $\alpha$-dependent tumor growth [32]. Moreover, unliganded PgR regulates ESR1 transcription via epigenetic modifications of the ESR1 promoter. PgR depletion results in ESR1 promoter hypermethylation, down-regulating expression of ER, which cannot be reversed after PgR re-expression [109].

The combined effect of estrogens and progestins on BC cells co-expressing ER $\alpha$ and $\mathrm{PgR}$ demonstrate that there is phenotypic antagonism between ER $\alpha$ and PgR. It has clinical consequences-in premenopausal patients, $\mathrm{PgR}$ has a more pronounced positive prognostic significance because of the availability of progesterone, which stimulates PgR signaling [110]. On the contrary, in post-menopausal females, progesterone levels are low, and thus are unable to produce a prominent phenotypic antagonism to $E R \alpha$, which makes PgR expression a less important predictive factor in older patients.

Once PgR expression is lost, other receptors such as ER $\beta$ or androgen receptor (AR) may more significantly modulate ER-dependent actions. In the absence of PgR, AR most likely enhances ER-mediated transcription. In the nuclei of $\mathrm{ER}(+) / \operatorname{PgR}(+) \mathrm{BC}$ cells, AR competes with ER and PgR to bind to DNA, thus interfering with the estrogen-mediated transcription. Conversely, when PgR is lost, another receptor, ER $\beta$, down-regulates ER $\alpha$ target genes, whereas AR enhances ER $\alpha$ target gene transcription and potentially contributes to tumor growth [111]. However, high AR expression is associated with prolonged relapsefree survival, lower grade, and lower number of affected lymph nodes in $\operatorname{ER} \alpha(+) / \operatorname{PgR}(-)$ $\mathrm{BC}$, thus the mechanistic role of $\mathrm{AR}$ and its influence on $\mathrm{ER} \alpha(+) / \operatorname{PgR}(-)$ tumor aggressiveness requires further studies $[112,113]$. 


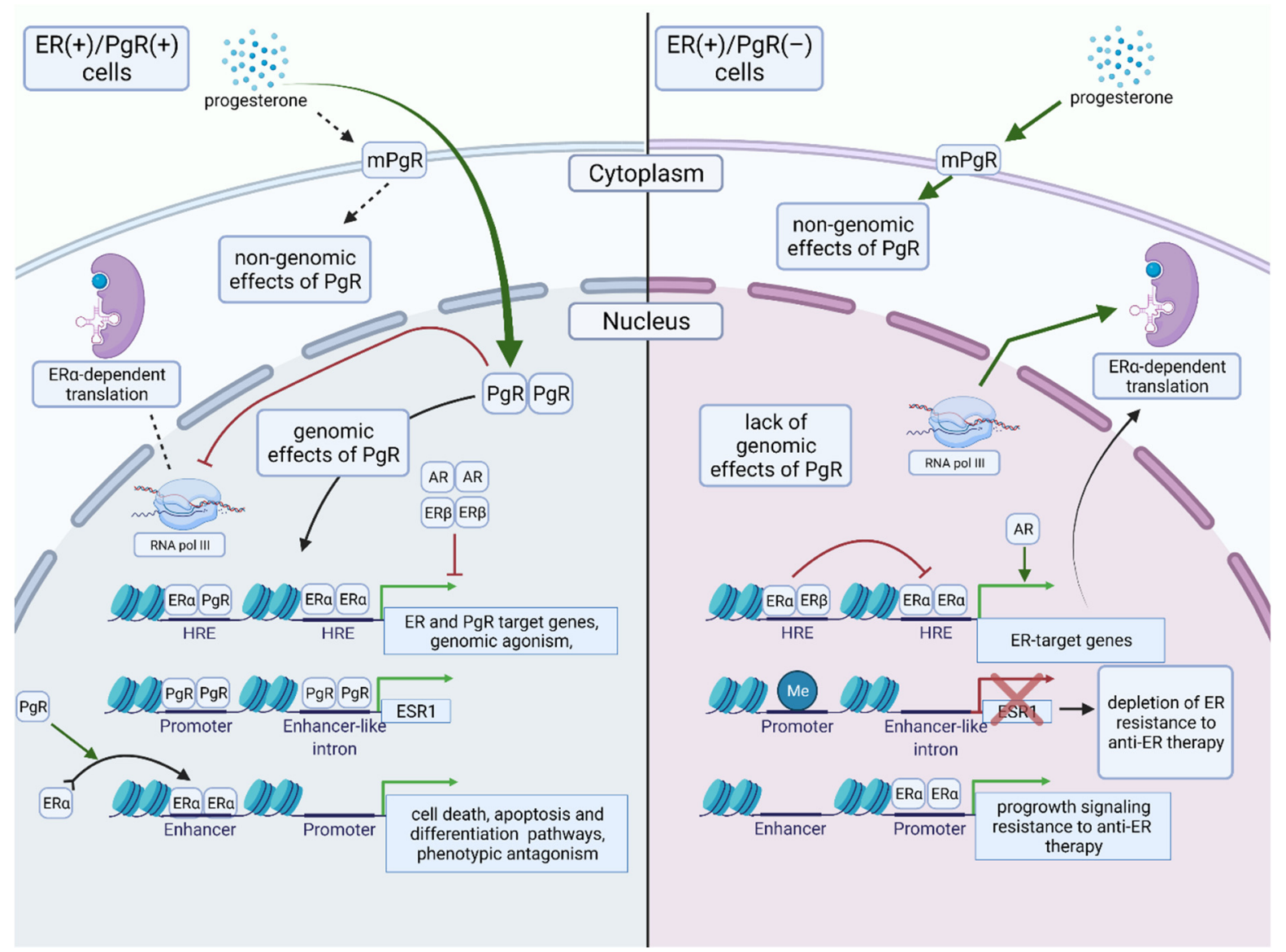

Figure 3. Biology of $\mathrm{ER} \alpha(+) / \operatorname{PgR}(+)$ and $\mathrm{ER} \alpha(+) / \operatorname{PgR}(-)$ breast cancer. Green arrows indicate stimulatory effects, red T-shaped lines depict inhibitory effects. In tumor cells co-expressing ER $\alpha$ and nuclear PgR the latter may exert both nongenomic and genomic effects. It regulates the expression of genes in a similar way to ER $\alpha$ (genomic agonism) but guides $\mathrm{ER} \alpha$ binding to chromatin to induce expression of genes associated with good outcomes (phenotypic antagonism). PgR interacts with translational machinery (mainly RNA polymerase III) reducing its availability for ER $\alpha$-dependent translation. Loss of nuclear PgR results in a shift of ER $\alpha$ role from distant enhancer to proximal promoter activating subset of genes associated with cancer progression. Depletion of PgR increases ESR1 gene promoter methylation and down-regulates ESR1. Other steroid receptors, i.e., ER and AR may exert different effects on ER $\alpha$-dependent genes expression in $\mathrm{ER} \alpha(+) / \operatorname{PgR}(+)$ and $\operatorname{ER} \alpha(+) / \operatorname{PgR}(-)$ breast cancers. For details, see text. Abbreviations: AR-androgen receptor; ESR1-estrogen receptor 1 gene; ER—estrogen receptor; HRE-hormone receptor element; (m)PgR—(membranous) progesterone receptor, RNA pol III-RNA polymerase III. Created with BioRender.com—accessed date 22 September 2021.

The loss of nuclear PgR expression does not imply loss of progestin responsiveness in BC cells [114]. Similarly to estrogens, progestins may act via membrane receptors (mPgRs), which have three subtypes: $\operatorname{mPgR} \alpha, \operatorname{mPgR} \beta$, and $\operatorname{mPgR} \gamma$, the first being the most prevalent in breast tissue [115]. In $\operatorname{PgR}(-) \mathrm{BC}$ cell lines progesterone produces an antiapoptotic response and activates MAPK and PI3K/Akt through mPgRs [114,116]. Expression of $\mathrm{mPgR}$ was correlated with HER2-overexpression, a number of lymph node metastases, and a worse prognosis in BC [117]. Thus, mPgRs might be important players in the biology of $\mathrm{ER} \alpha(+) / \operatorname{PgR}(-) \mathrm{BC}$ s providing pro-growth signals. Nevertheless, some in vitro studies utilizing $\mathrm{BC}$ cell lines demonstrated that $\operatorname{mPgR} \alpha$ mediates antiproliferative and antimetastatic signaling of progesterone [118,119], although the effects of mPgRs are potentially dependent on the model (in vitro vs. in vivo or clinical studies), progesterone levels, and competition with nuclear receptors. Of note, there is an inverse relationship between nuclear PgR and mPgR [117]. 
A recent study in PgR-low/null tumors defined phospho-PgR target gene sets (ERBB2, $P A X 2, A H R, A R$, and RUNX2) which regulate cancer stem cell biology and increase tumor heterogeneity [85]. Paradoxically, antiprogestin treatment may possibly be effective in these clinically $\operatorname{PgR}(-)$ tumors, preventing the development of endocrine resistance [85]. However, not all antiprogestins are equally adequate to this approach, since it was shown that in the presence of progesterone onapristone blocks Ser294 phosphorylation, whereas mifepristone and aglepristone induce Ser294 phosphorylation, behaving similar to partial agonists of PgR [85]. Phase I study of onapristone in heavily pre-treated, metastatic endometrial, ovarian, and $\mathrm{BC}$ showed promising results and proposed activated progesterone receptor as a potential predictive factor [120].

The understanding of PgR significance in $\mathrm{BC}$ is further complicated by the coexistence of its isoforms, as phosphorylated PgR-A is a more potent driver of cancer stem cell expansion, whereas PgR-B is involved in BC cells proliferation [121]. In normal mammary gland tissue, the levels of PgR-A and PgR-B are similar, while the ratio is disturbed during cancer transformation, usually resulting in PgR-A prevalence [122]. In vitro studies demonstrated that the PgR-A/PgR-B ratio determines the functional outcome of PgR action, including both the target genes and response to hormones and growth factors [123]. This observation was further confirmed in clinics because a high PgR-A/PgR-B ratio was indicative of a shorter time to relapse in patients treated with tamoxifen within the ATAC trial [124]. Interestingly, it is speculated that tamoxifen resistance and the worse prognosis are associated solely with methylation of PGRA promoter, resulting in the functional predominance of PgR-B [57]. High frequency of ER $\alpha: P g R-B$ interaction was predictive of relapse on an adjuvant AI, and in some cases, a substantial amount of ER $\alpha$ :PgR-B interactions coexisted with a lack of IHC-detectable PgR expression [125].

It was recently shown that among HER2-negative tumors $\operatorname{ER} \alpha(+) / \operatorname{PgR}(-) \mathrm{BC}$ display distinctive tyrosine kinases profiles [126], characterized by higher overall kinase activity than double-positive tumors, with RAS, PI3K, and ErbB signaling being mostly responsible for these differences. Four kinases showed significant expression differences between $\operatorname{PgR}(-)$ and $\operatorname{PgR}(+)$ tumors: fibroblast growth factor receptor 4 (FGFR4) and LCK were up-regulated, whereas Fyn-related kinase (FRK) and macrophage-stimulating 1 receptor (MST1R) down-regulated in $\operatorname{PgR}(-)$ cases. Interestingly, all these kinases are directly regulated by progesterone. Moreover, Tahiri et al. identified 24 kinase-encoding genes differentially expressed between double-positive and $\operatorname{PgR}(-)$ tumors, dividing ER(+)/HER2(-) BCs into two prognostically distinct clusters: cluster 1 comprising mostly $\operatorname{PgR}(+)$ patients with a better prognosis, and cluster 2 characterized by worse prognosis and the predominance of $\operatorname{PgR}(-)$ patients [126]. Additionally, $\operatorname{PgR}(-)$ patients in cluster 2 had inferior survival to $\operatorname{PgR}(-)$ patients in cluster 1 . Unfortunately, the association between the clusters and luminal A vs. B phenotype was not studied. Importantly, these associations are not seen in HER2(+) samples, suggesting that the effects of HER2 are dominant. This is further supported by our study on single hormone receptor BC, in which miRNA profiles of single hormone receptor-positive breast cancers were mainly dependent on the status of HER2, rather than on ER $\alpha / \operatorname{PgR}$ status [83].

\section{Conclusions}

Lack of PgR expression in ER $\alpha(+) B C$ has multiple potential explanations but the molecular, pathological and clinical heterogeneity of this group remains underappreciated. The biology of $\operatorname{ER} \alpha(+) / \operatorname{PgR}(-) \mathrm{BC}$ is context-dependent, being highly modulated by the cross-talk between growth factors receptors and nuclear or membranous steroid hormone receptors. Novel therapeutic targets as microRNAs, epigenetic modifications, tyrosine kinases, and transcriptionally overactive PgR should be further investigated in the future. Identification of the mechanism of PgR loss in each patient seems challenging, yet it may provide important information on the biology of the tumor and predict its responsiveness to the therapy. Finally, future studies should focus on the investigation of novel biomarkers 
predicting the disease course, as well as its response to endocrine and chemotherapy in this distinctive group of patients.

Author Contributions: Conceptualization: M.K., M.P., W.B., E.S.; Methodology: M.K.; Writingoriginal draft: M.K., M.P.; Visualization: M.K., M.P.; Resources: W.B., E.S.; Writing-Review \& Editing: W.B., E.S.; Funding Acquisition: E.S. All authors have read and agreed to the published version of the manuscript.

Funding: This research was funded by the National Science Centre, Poland (grant 2017/25/B/NZ5/00656).

Acknowledgments: Figures and graphical abstract were created with Biorender.com.

Conflicts of Interest: The authors declare no conflict of interest. Declaration of interest: M.K., M.P. and W.B. declare no conflict of interest. E.S. discloses relationships with the following entities: Egis, Eli Lilly, Genomic Health, Novartis, Pfizer.

\section{References}

1. Patel, H.K.; Bihani, T. Selective estrogen receptor modulators (SERMs) and selective estrogen receptor degraders (SERDs) in cancer treatment. Pharmacol. Ther. 2018, 186, 1-24. [CrossRef]

2. Nordenskjöld, A.; Fohlin, H.; Fornander, T.; Löfdahl, B.; Skoog, L.; Stål, O. Progesterone receptor positivity is a predictor of long-term benefit from adjuvant tamoxifen treatment of estrogen receptor positive breast cancer. Breast Cancer Res. Treat. 2016, 160, 313-322. [CrossRef]

3. Olivotto, I.A.; Truong, P.T.; Speers, C.H.; Bernstein, V.; Allan, S.J.; Kelly, S.J.; Lesperance, M.L. Time to stop progesterone receptor testing in breast cancer management. J. Clin. Oncol. 2004, 22, 1769-1770. [CrossRef] [PubMed]

4. Colomer, R.; Beltran, M.; Dorcas, J.; Cortes-Funes, H.; Hornedo, J.; Valentin, V.; Vargas, C.; Mendiola, C.; Ciruelos, E. It Is Not Time to Stop Progesterone Receptor Testing in Breast Cancer. J. Clin. Oncol. 2005, 23, 3868-3869. [CrossRef] [PubMed]

5. Braun, L.; Mietzsch, F.; Seibold, P.; Schneeweiss, A.; Schirmacher, P.; Chang-Claude, J.; Peter Sinn, H.; Aulmann, S. Intrinsic breast cancer subtypes defined by estrogen receptor signalling-Prognostic relevance of progesterone receptor loss. Mod. Pathol. 2013, 26, 1161-1171. [CrossRef] [PubMed]

6. Prat, A.; Cheang, M.C.U.; Martín, M.; Parker, J.S.; Carrasco, E.; Caballero, R.; Tyldesley, S.; Gelmon, K.; Bernard, P.S.; Nielsen, T.O.; et al Prognostic Significance of Progesterone Receptor-Positive Tumor Cells within Immunohistochemically Defined Luminal A Breast Cancer. J. Clin. Oncol. 2013, 31, 203-209. [CrossRef]

7. Allison, K.H.; Hammond, M.E.H.; Dowsett, M.; McKernin, S.E.; Carey, L.A.; Fitzgibbons, P.L.; Hayes, D.F.; Lakhani, S.R.; Chavez-MacGregor, M.; Perlmutter, J.; et al. Estrogen and Progesterone Receptor Testing in Breast Cancer: ASCO/CAP Guideline Update. J. Clin. Oncol. 2020, 38, 1346-1366. [CrossRef] [PubMed]

8. Kunc, M.; Biernat, W.; Senkus-Konefka, E. Estrogen receptor-negative progesterone receptor-positive breast cancer- “Nobody's land“ or just an artifact? Cancer Treat. Rev. 2018, 67, 78-87. [CrossRef]

9. Beltjens, F.; Molly, D.; Bertaut, A.; Richard, C.; Desmoulins, I.; Loustalot, C.; Charon-Barra, C.; Courcet, E.; Bergeron, A.; Ladoire, S.; et al. ER-/PR+ breast cancer: A distinct entity, which is morphologically and molecularly close to triple-negative breast cancer. Int. J. Cancer 2021, 149, 200-213. [CrossRef]

10. Li, Z.; Tu, Y.; Wu, Q.; Wang, Z.; Li, J.; Zhang, Y.; Sun, S. Clinical Characteristics and Outcomes of Single Versus Double Hormone Receptor-Positive Breast Cancer in 2 Large Databases. Clin. Breast Cancer 2019, 20, e151-e163. [CrossRef]

11. Li, Y.; Yang, D.; Yin, X.; Zhang, X.; Huang, J.; Wu, Y.; Wang, M.; Yi, Z.; Li, H.; Li, H.; et al. Clinicopathological Characteristics and Breast Cancer-Specific Survival of Patients with Single Hormone Receptor-Positive Breast Cancer. JAMA Netw. Open 2020, 3, e1918160. [CrossRef]

12. Zattarin, E.; Leporati, R.; Ligorio, F.; Lobefaro, R.; Vingiani, A.; Pruneri, G.; Vernieri, C. Hormone Receptor Loss in Breast Cancer: Molecular Mechanisms, Clinical Settings, and Therapeutic Implications. Cells 2020, 9, 2644. [CrossRef]

13. Bae, S.Y.; Kim, S.; Lee, J.H.; Lee, H.; Lee, S.K.; Kil, W.H.; Kim, S.W.; Lee, J.E.; Nam, S.J. Poor prognosis of single hormone receptor-positive breast cancer: Similar outcome as triple-negative breast cancer. BMC Cancer 2015, 15, 138. [CrossRef]

14. Dunnwald, L.K.; Rossing, M.; Li, C.I. Hormone receptor status, tumor characteristics, and prognosis: A prospective cohort of breast cancer patients. Breast Cancer Res. 2007, 9, R6. [CrossRef]

15. Dembinski, R.; Prasath, V.; Bohnak, C.; Siotos, C.; Sebai, M.E.; Psoter, K.; Gani, F.; Canner, J.; Camp, M.S.; Azizi, A.; et al. Estrogen Receptor Positive and Progesterone Receptor Negative Breast Cancer: The Role of Hormone Therapy. Horm. Cancer 2020, 11, 148-154. [CrossRef]

16. Thakkar, J.P.; Mehta, D.G. A Review of an Unfavorable Subset of Breast Cancer: Estrogen Receptor Positive Progesterone Receptor Negative. Oncologist 2011, 16, 276-285. [CrossRef]

17. Fahlén, M.; Zhang, H.; Löfgren, L.; Masironi, B.; von Schoultz, E.; von Schoultz, B.O.; Sahlin, L. Expression of Progesterone and Androgen Receptors in the Breast of Premenopausal Women, Considering Menstrual Phase. Anticancer Res. 2018, 38, 1499-1510. [CrossRef] 
18. Bao, P.-P.; Shu, X.O.; Gao, Y.-T.; Zheng, Y.; Cai, H.; Deming, S.L.; Ruan, Z.-X.; Su, Y.; Gu, K.; Lu, W.; et al. Association of Hormone-Related Characteristics and Breast Cancer Risk by Estrogen Receptor/Progesterone Receptor Status in the Shanghai Breast Cancer Study. Am. J. Epidemiol. 2011, 174, 661-671. [CrossRef]

19. Fournier, A.; Fabre, A.; Mesrine, S.; Boutron-Ruault, M.-C.; Berrino, F.; Clavel-Chapelon, F. Use of Different Postmenopausal Hormone Therapies and Risk of Histology- and Hormone Receptor-Defined Invasive Breast Cancer. J. Clin. Oncol. 2008, 26, 1260-1268. [CrossRef] [PubMed]

20. Nevels, R.M.; Gontkovsky, S.T.; Williams, B.E. Paroxetine-The antidepressant from hell? Probably not, but caution required. Psychopharmacol. Bull. 2016, 46, 77-104.

21. Salmen, J.; Neugebauer, J.; Fasching, P.A.; Haeberle, L.; Huober, J.; Wöckel, A.; Rauh, C.; Schuetz, F.; Weissenbacher, T.; Kost, B.; et al. Pooled analysis of the prognostic relevance of progesterone receptor status in five German cohort studies. Breast Cancer Res. Treat. 2014, 148, 143-151. [CrossRef] [PubMed]

22. Ueno, T.; Saji, S.; Chiba, T.; Kamma, H.; Isaka, H.; Itoh, H.; Imi, K.; Miyamoto, K.; Tada, M.; Sasano, H.; et al. Progesterone receptor expression in proliferating cancer cells of hormone-receptor-positive breast cancer. Tumor Biol. 2018, 40, 101042831881102. [CrossRef]

23. Davies, C.; Godwin, J.; Gray, R.; Clarke, M.; Cutter, D.; Darby, S.; McGale, P.; Pan, H.C.; Taylor, C.; Early Breast Cancer Trialists' Collaborative Group (EBCTCG); et al. Relevance of breast cancer hormone receptors and other factors to the efficacy of adjuvant tamoxifen: Patient-level meta-analysis of randomised trials. Lancet 2011, 378, 771-784. [CrossRef]

24. Ravdin, P.M.; Green, S.; Dorr, T.M.; McGuire, W.L.; Fabian, C.; Pugh, R.P.; Carter, R.D.; Rivkin, S.E.; Borst, J.R.; Belt, R.J. Prognostic significance of progesterone receptor levels in estrogen receptor-positive patients with metastatic breast cancer treated with tamoxifen: Results of a prospective Southwest Oncology Group study. J. Clin. Oncol. 1992, 10, 1284-1291. [CrossRef]

25. Gao, J.J.; Cheng, J.; Bloomquist, E.; Sanchez, J.; Wedam, S.B.; Singh, H.; Amiri-Kordestani, L.; Ibrahim, A.; Sridhara, R.; Goldberg, K.B.; et al. CDK4/6 inhibitor treatment for patients with hormone receptor-positive, HER2-negative, advanced or metastatic breast cancer: A US Food and Drug Administration pooled analysis. Lancet Oncol. 2020, 21, 250-260. [CrossRef]

26. Petruolo, O.A.; Pilewskie, M.; Patil, S.; Barrio, A.V.; Stempel, M.; Wen, H.Y.; Morrow, M. Standard Pathologic Features Can Be Used to Identify a Subset of Estrogen Receptor-Positive, HER2 Negative Patients Likely to Benefit from Neoadjuvant Chemotherapy. Ann. Surg. Oncol. 2017, 24, 2556-2562. [CrossRef]

27. Van Mackelenbergh, M.T.; Denkert, C.; Nekljudova, V.; Karn, T.; Schem, C.; Marmé, F.; Stickeler, E.; Jackisch, C.; Hanusch, C.; Huober, J.; et al. Outcome after neoadjuvant chemotherapy in estrogen receptor-positive and progesterone receptor-negative breast cancer patients: A pooled analysis of individual patient data from ten prospectively randomized controlled neoadjuvant trials. Breast Cancer Res. Treat. 2018, 167, 59-71. [CrossRef] [PubMed]

28. Davey, M.G.; Ryan, É.J.; Folan, P.J.; O’Halloran, N.; Boland, M.R.; Barry, M.K.; Sweeney, K.J.; Malone, C.M.; McLaughlin, R.J.; Kerin, M.J.; et al. The impact of progesterone receptor negativity on oncological outcomes in oestrogen-receptor-positive breast cancer. BJS Open 2021, 5, zrab040. [CrossRef]

29. Johnson, P.A.; Bonomi, P.D.; Anderson, K.M.; Wolter, J.M.; Bacon, L.D.; Rossof, A.H.; Economou, S.G. Progesterone receptor level as a predictor of response to megestrol acetate in advanced breast cancer: A retrospective study. Cancer Treat. Rep. 1983, 67, 717-720. [PubMed]

30. Cui, X.; Schiff, R.; Arpino, G.; Osborne, C.K.; Lee, A.V. Biology of progesterone receptor loss in breast cancer and its implications for endocrine therapy. J. Clin. Oncol. 2005, 23, 7721-7735. [CrossRef] [PubMed]

31. Liu, X.-Y.; Ma, D.; Xu, X.-E.; Jin, X.; Yu, K.-D.; Jiang, Y.-Z.; Shao, Z.-M. Genomic Landscape and Endocrine-Resistant Subgroup in Estrogen Receptor-Positive, Progesterone Receptor-Negative, and HER2-Negative Breast Cancer. Theranostics 2018, 8, 6386-6399. [CrossRef]

32. Mohammed, H.; Russell, I.A.; Stark, R.; Rueda, O.M.; Hickey, T.E.; Tarulli, G.A.; Serandour, A.A.; Birrell, S.N.; Bruna, A.; Saadi, A.; et al. Progesterone receptor modulates ER $\alpha$ action in breast cancer. Nature 2015, 523, 313-317. [CrossRef]

33. Lopez, G.; Costanza, J.; Colleoni, M.; Fontana, L.; Ferrero, S.; Miozzo, M.; Fusco, N. Molecular Insights into the Classification of Luminal Breast Cancers: The Genomic Heterogeneity of Progesterone-Negative Tumors. Int. J. Mol. Sci. 2019, 20, 510. [CrossRef]

34. Martínez-Jiménez, F.; Muiños, F.; Sentís, I.; Deu-Pons, J.; Reyes-Salazar, I.; Arnedo-Pac, C.; Mularoni, L.; Pich, O.; Bonet, J.; Kranas, H.; et al. A compendium of mutational cancer driver genes. Nat. Rev. Cancer 2020, 20, 555-572. [CrossRef]

35. Fowler, A.M.; Salem, K.; DeGrave, M.; Ong, I.M.; Rassman, S.; Powers, G.L.; Kumar, M.; Michel, C.J.; Mahajan, A.M. Progesterone Receptor Gene Variants in Metastatic Estrogen Receptor Positive Breast Cancer. Horm. Cancer 2020, 11, 63-75. [CrossRef] [PubMed]

36. Dowsett, M.; Cuzick, J.; Wale, C.; Howell, T.; Houghton, J.; Baum, M. Retrospective Analysis of Time to Recurrence in the ATAC Trial According to Hormone Receptor Status: An Hypothesis-Generating Study. J. Clin. Oncol. 2005, 23, 7512-7517. [CrossRef] [PubMed]

37. Rose-Hellekant, T.A.; Schroeder, M.D.; Brockman, J.L.; Zhdankin, O.; Bolstad, R.; Chen, K.S.; Gould, M.N.; Schuler, L.A.; Sandgren, E.P. Estrogen receptor-positive mammary tumorigenesis in TGF $\alpha$ transgenic mice progresses with progesterone receptor loss. Oncogene 2007, 26, 5238-5246. [CrossRef]

38. Arendt, L.M.; Grafwallner-Huseth, T.L.; Schuler, L.A. Prolactin-Growth Factor Crosstalk Reduces Mammary Estrogen Responsiveness Despite Elevated ER $\alpha$ Expression. Am. J. Pathol. 2009, 174, 1065-1074. [CrossRef] [PubMed] 
39. Grimm, S.L.; Hartig, S.M.; Edwards, D.P. Progesterone Receptor Signaling Mechanisms. J. Mol. Biol. 2016, 428, 3831-3849. [CrossRef]

40. Yang, S.; Jia, Y.; Liu, X.; Winters, C.; Wang, X.; Zhang, Y.; Devor, E.J.; Hovey, A.M.; Reyes, H.D.; Xiao, X.; et al. Systematic dissection of the mechanisms underlying progesterone receptor downregulation in endometrial cancer. Oncotarget 2014, 5, $9783-9797$. [CrossRef] [PubMed]

41. Daniel, A.R.; Faivre, E.J.; Lange, C.A. Phosphorylation-Dependent Antagonism of Sumoylation Derepresses Progesterone Receptor Action in Breast Cancer Cells. Mol. Endocrinol. 2007, 21, 2890-2906. [CrossRef] [PubMed]

42. Lange, C.A.; Shen, T.; Horwitz, K.B. Phosphorylation of human progesterone receptors at serine-294 by mitogen-activated protein kinase signals their degradation by the 26S proteasome. Proc. Natl. Acad. Sci. USA 2000, 97, 1032-1037. [CrossRef]

43. Daniel, A.R.; Gaviglio, A.L.; Czaplicki, L.M.; Hillard, C.J.; Housa, D.; Lange, C.A. The progesterone receptor hinge region regulates the kinetics of transcriptional responses through acetylation, phosphorylation, and nuclear retention. Mol. Endocrinol. 2010, 24, 2126-2138. [CrossRef] [PubMed]

44. Knutson, T.P.; Daniel, A.R.; Fan, D.; Silverstein, K.A.; Covington, K.R.; Fuqua, S.A.; Lange, C.A. Phosphorylated and sumoylationdeficient progesterone receptors drive proliferative gene signatures during breast cancer progression. Breast Cancer Res. 2012, 14, R95. [CrossRef]

45. Zhang, C.; Mori, M.; Gao, S.; Li, A.; Hoshino, I.; Aupperlee, M.D.; Haslam, S.Z.; Xiao, H. Tip30 Deletion in MMTV-Neu Mice Leads to Enhanced EGFR Signaling and Development of Estrogen Receptor-Positive and Progesterone Receptor-Negative Mammary Tumors. Cancer Res. 2010, 70, 10224-10233. [CrossRef]

46. Pérez, T.; Makrestsov, N.; Garatt, J.; Torlakovic, E.; Gilks, C.B.; Mallett, S. Modeling Canadian Quality Control Test Program for Steroid Hormone Receptors in Breast Cancer. Appl. Immunohistochem. Mol. Morphol. 2016, 24, 679-687. [CrossRef]

47. Cork, D.M.W.; Lennard, T.W.J.; Tyson-Capper, A.J. Progesterone receptor (PR) variants exist in breast cancer cells characterised as PR negative. Tumor Biol. 2012, 33, 2329-2340. [CrossRef] [PubMed]

48. Kechagioglou, P.; Papi, R.M.; Provatopoulou, X.; Kalogera, E.; Papadimitriou, E.; Grigoropoulos, P.; Nonni, A.; Zografos, G.; Kyriakidis, D.A.; Gounaris, A. Tumor suppressor PTEN in breast cancer: Heterozygosity, mutations and protein expression. Anticancer Res. 2014, 34, 1387-1400.

49. Tokunaga, E.; Oki, E.; Kimura, Y.; Yamanaka, T.; Egashira, A.; Nishida, K.; Koga, T.; Morita, M.; Kakeji, Y.; Maehara, Y. Coexistence of the loss of heterozygosity at the PTEN locus and HER2 overexpression enhances the Akt activity thus leading to a negative progesterone receptor expression in breast carcinoma. Breast Cancer Res. Treat. 2007, 101, 249-257. [CrossRef]

50. Shore, A.N.; Chang, C.-H.; Kwon, O.-J.; Weston, M.C.; Zhang, M.; Xin, L.; Rosen, J.M. PTEN is required to maintain luminal epithelial homeostasis and integrity in the adult mammary gland. Dev. Biol. 2016, 409, 202-217. [CrossRef]

51. Calvo, V.; Beato, M. BRCA1 Counteracts Progesterone Action by Ubiquitination Leading to Progesterone Receptor Degradation and Epigenetic Silencing of Target Promoters. Cancer Res. 2011, 71, 3422-3431. [CrossRef]

52. Sanford, R.A.; Song, J.; Gutierrez-Barrera, A.M.; Profato, J.; Woodson, A.; Litton, J.K.; Bedrosian, I.; Albarracin, C.T.; Valero, V.; Arun, B. High incidence of germline BRCA mutation in patients with ER low-positive/PR low-positive/HER-2 neu negative tumors. Cancer 2015, 121, 3422-3427. [CrossRef] [PubMed]

53. Lapidus, R.G.; Ferguson, A.T.; Ottaviano, Y.L.; Parl, F.F.; Smith, H.S.; Weitzman, S.A.; Baylin, S.B.; Issa, J.P.; Davidson, N.E. Methylation of estrogen and progesterone receptor gene 5' CpG islands correlates with lack of estrogen and progesterone receptor gene expression in breast tumors. Clin. Cancer Res. 1996, 2, 805-810. [PubMed]

54. Mirza, S.; Sharma, G.; Prasad, C.P.; Parshad, R.; Srivastava, A.; Gupta, S.D.; Ralhan, R. Promoter hypermethylation of TMS1, BRCA1, ER $\alpha$ and PRB in serum and tumor DNA of invasive ductal breast carcinoma patients. Life Sci. 2007, 81, 280-287. [CrossRef] [PubMed]

55. Mc Cormack, O.; Chung, W.Y.; Fitzpatrick, P.; Cooke, F.; Flynn, B.; Harrison, M.; Fox, E.; Gallagher, E.; McGoldrick, A.; Dervan, P.A.; et al. Progesterone receptor B (PRB) promoter hypermethylation in sporadic breast cancer. Breast Cancer Res. Treat. 2008, 111, 45-53. [CrossRef]

56. Gaudet, M.M.; Campan, M.; Figueroa, J.D.; Yang, X.R.; Lissowska, J.; Peplonska, B.; Brinton, L.A.; Rimm, D.L.; Laird, P.W.; Garcia-Closas, M.; et al. DNA Hypermethylation of ESR1 and PGR in Breast Cancer: Pathologic and Epidemiologic Associations. Cancer Epidemiol. Biomark. Prev. 2009, 18, 3036-3043. [CrossRef]

57. Pathiraja, T.N.; Shetty, P.B.; Jelinek, J.; He, R.; Hartmaier, R.; Margossian, A.L.; Hilsenbeck, S.G.; Issa, J.-P.J.; Oesterreich, S. Progesterone Receptor Isoform-Specific Promoter Methylation: Association of PRA Promoter Methylation with Worse Outcome in Breast Cancer Patients. Clin. Cancer Res. 2011, 17, 4177-4186. [CrossRef]

58. Pirouzpanah, S.; Taleban, F.-A.; Mehdipour, P.; Sabour, S.; Atri, M. Hypermethylation pattern of ESR and PgR genes and lacking estrogen and progesterone receptors in human breast cancer tumors: ER/PR subtypes. Cancer Biomark. 2018, 21, 621-638. [CrossRef] [PubMed]

59. Fiegl, H.; Millinger, S.; Goebel, G.; Müller-Holzner, E.; Marth, C.; Laird, P.W.; Widschwendter, M. Breast Cancer DNA Methylation Profiles in Cancer Cells and Tumor Stroma: Association with HER-2/neu Status in Primary Breast Cancer. Cancer Res. 2006, 66, 29-33. [CrossRef] [PubMed]

60. Badia, E.; Oliva, J.; Balaguer, P.; Cavaillès, V. Tamoxifen resistance and epigenetic modifications in breast cancer cell lines. Curr. Med. Chem. 2007, 14, 3035-3045. [CrossRef] [PubMed] 
61. Stone, A.; Valdés-Mora, F.; Gee, J.M.W.; Farrow, L.; McClelland, R.A.; Fiegl, H.; Dutkowski, C.; McCloy, R.A.; Sutherland, R.L.; Musgrove, E.A.; et al. Tamoxifen-Induced Epigenetic Silencing of Oestrogen-Regulated Genes in Anti-Hormone Resistant Breast Cancer. PLoS ONE 2012, 7, e40466. [CrossRef] [PubMed]

62. Raha, P.; Thomas, S.; Thurn, K.T.; Park, J.; Munster, P.N. Combined histone deacetylase inhibition and tamoxifen induces apoptosis in tamoxifen-resistant breast cancer models, by reversing Bcl-2 overexpression. Breast Cancer Res. 2015, 17, 26. [CrossRef] [PubMed]

63. Bredfeldt, T.G.; Greathouse, K.L.; Safe, S.H.; Hung, M.-C.; Bedford, M.T.; Walker, C.L. Xenoestrogen-Induced Regulation of EZH2 and Histone Methylation via Estrogen Receptor Signaling to PI3K/AKT. Mol. Endocrinol. 2010, 24, 993-1006. [CrossRef] [PubMed]

64. Fleury, L.; Gerus, M.; Lavigne, A.C.; Richard-Foy, H.; Bystricky, K. Eliminating epigenetic barriers induces transient hormoneregulated gene expression in estrogen receptor negative breast cancer cells. Oncogene 2008, 27, 4075-4085. [CrossRef] [PubMed]

65. Billam, M.; Sobolewski, M.D.; Davidson, N.E. Effects of a novel DNA methyltransferase inhibitor zebularine on human breast cancer cells. Breast Cancer Res. Treat. 2010, 120, 581-592. [CrossRef] [PubMed]

66. Kavlashvili, T.; Jia, Y.; Dai, D.; Meng, X.; Thiel, K.W.; Leslie, K.K.; Yang, S. Inverse Relationship between Progesterone Receptor and Myc in Endometrial Cancer. PLoS ONE 2016, 11, e0148912. [CrossRef]

67. Higa, G.M.; Fell, R.G. Sex Hormone Receptor Repertoire in Breast Cancer. Int. J. Breast Cancer 2013, 2013, 284036. [CrossRef]

68. Mandušić, V.; Popov-Čeleketić, D.; Nešković-Konstantinović, Z.; Kanjer, K.; Bozovic, A.; Nikolić-Vukosavljević, D. Levels of estrogen receptor $\beta$ splice variant $(\mathrm{ER} \beta \Delta 5)$ mRNA correlates with progesterone receptor in breast carcinomas. Arch. Biol. Sci. 2010, 62, 257-262. [CrossRef]

69. Saji, S.; Omoto, Y.; Shimizu, C.; Warner, M.; Hayashi, Y.; Horiguchi, S.I.; Watanabe, T.; Hayashi, S.I.; Gustafsson, J.Å.; Toi, M. Expression of estrogen receptor (ER) $\beta c x$ protein in ER $\alpha$-positive breast cancer: Specific correlation with progesterone receptor. Cancer Res. 2002, 62, 4849-4853.

70. Mahboobifard, F.; Dargahi, L.; Jorjani, M.; Ramezani Tehrani, F.; Pourgholami, M.H. The role of ER $\alpha 36$ in cell type-specific functions of estrogen and cancer development. Pharmacol. Res. 2021, 163, 105307. [CrossRef]

71. Konan, H.-P.; Kassem, L.; Omarjee, S.; Surmieliova-Garnès, A.; Jacquemetton, J.; Cascales, E.; Rezza, A.; Trédan, O.; Treilleux, I.; Poulard, C.; et al. ER $\alpha-36$ regulates progesterone receptor activity in breast cancer. Breast Cancer Res. 2020, 22, 50. [CrossRef] [PubMed]

72. Groenendijk, F.H.; Zwart, W.; Floore, A.; Akbari, S.; Bernards, R. Estrogen receptor splice variants as a potential source of false-positive estrogen receptor status in breast cancer diagnostics. Breast Cancer Res. Treat. 2013, 140, 475-484. [CrossRef]

73. Groenendijk, F.H.; Treece, T.; Yoder, E.; Baron, P.; Beitsch, P.; Audeh, W.; Dinjens, W.N.M.; Bernards, R.; Whitworth, P. Estrogen receptor variants in ER-positive basal-type breast cancers responding to therapy like ER-negative breast cancers. NPJ Breast Cancer 2019, 5, 15. [CrossRef] [PubMed]

74. Esquela-Kerscher, A.; Slack, F.J. Oncomirs-MicroRNAs with a role in cancer. Nat. Rev. Cancer 2006, 6, 259-269. [CrossRef]

75. Fabian, M.R.; Sonenberg, N. The mechanics of miRNA-mediated gene silencing: A look under the hood of miRISC. Nat. Struct. Mol. Biol. 2012, 19, 586-593. [CrossRef]

76. Klinge, C.M. miRNAs and estrogen action. Trends Endocrinol. Metab. 2012, 23, 223-233. [CrossRef]

77. Younger, S.T.; Corey, D.R. Transcriptional gene silencing in mammalian cells by miRNA mimics that target gene promoters. Nucleic Acids Res. 2011, 39, 5682-5691. [CrossRef]

78. Cui, W.; Li, Q.; Feng, L.; Ding, W. MiR-126-3p regulates progesterone receptors and involves development and lactation of mouse mammary gland. Mol. Cell. Biochem. 2011, 355, 17-25. [CrossRef]

79. Gilam, A.; Shai, A.; Ashkenazi, I.; Sarid, L.A.; Drobot, A.; Bickel, A.; Shomron, N. MicroRNA regulation of progesterone receptor in breast cancer. Oncotarget 2017, 8, 25963-25976. [CrossRef] [PubMed]

80. Maillot, G.; Lacroix-Triki, M.; Pierredon, S.; Gratadou, L.; Schmidt, S.; Bénès, V.; Roché, H.; Dalenc, F.; Auboeuf, D.; Millevoi, S.; et al. Widespread Estrogen-Dependent Repression of microRNAs Involved in Breast Tumor Cell Growth. Cancer Res. 2009, 69, 8332-8340. [CrossRef] [PubMed]

81. Godbole, M.; Chandrani, P.; Gardi, N.; Dhamne, H.; Patel, K.; Yadav, N.; Gupta, S.; Badwe, R.; Dutt, A. miR-129-2 mediates down-regulation of progesterone receptor in response to progesterone in breast cancer cells. Cancer Biol. Ther. 2017, 18, 801-805. [CrossRef]

82. Cochrane, D.R.; Jacobsen, B.M.; Connaghan, K.D.; Howe, E.N.; Bain, D.L.; Richer, J.K. Progestin regulated miRNAs that mediate progesterone receptor action in breast cancer. Mol. Cell. Endocrinol. 2012, 355, 15-24. [CrossRef] [PubMed]

83. Kunc, M.; Popęda, M.; Szałkowska, A.; Niemira, M.; Bieńkowski, M.; Pęksa, R.; Łacko, A.; Radecka, B.S.; Braun, M.; Pikiel, J.; et al. microRNA Expression Profile in Single Hormone Receptor-Positive Breast Cancers Is Mainly Dependent on HER2 Status-A Pilot Study. Diagnostics 2020, 10, 617. [CrossRef] [PubMed]

84. Finlay-Schultz, J.; Gillen, A.E.; Brechbuhl, H.M.; Ivie, J.J.; Matthews, S.B.; Jacobsen, B.M.; Bentley, D.L.; Kabos, P.; Sartorius, C.A. Breast Cancer Suppression by Progesterone Receptors Is Mediated by Their Modulation of Estrogen Receptors and RNA Polymerase III. Cancer Res. 2017, 77, 4934-4946. [CrossRef]

85. Knutson, T.P.; Truong, T.H.; Ma, S.; Brady, N.J.; Sullivan, M.E.; Raj, G.; Schwertfeger, K.L.; Lange, C.A. Posttranslationally modified progesterone receptors direct ligand-specific expression of breast cancer stem cell-associated gene programs. J. Hematol. Oncol. 2017, 10, 89. [CrossRef] 
86. Martin, E.C.; Rhodes, L.V.; Elliott, S.; Krebs, A.E.; Nephew, K.P.; Flemington, E.K.; Collins-Burow, B.M.; Burow, M.E. microRNA regulation of mammalian target of rapamycin expression and activity controls estrogen receptor function and RAD001 sensitivity. Mol. Cancer 2014, 13, 229. [CrossRef]

87. Bachelot, T.; Bourgier, C.; Cropet, C.; Ray-Coquard, I.; Ferrero, J.-M.; Freyer, G.; Abadie-Lacourtoisie, S.; Eymard, J.-C.; Debled, M.; Spaëth, D.; et al. Randomized Phase II Trial of Everolimus in Combination with Tamoxifen in Patients with Hormone ReceptorPositive, Human Epidermal Growth Factor Receptor 2-Negative Metastatic Breast Cancer with Prior Exposure to Aromatase Inhibitors: A GINECO Study. J. Clin. Oncol. 2012, 30, 2718-2724. [CrossRef]

88. Kornblum, N.; Zhao, F.; Manola, J.; Klein, P.; Ramaswamy, B.; Brufsky, A.; Stella, P.J.; Burnette, B.; Telli, M.; Makower, D.F.; et al. Randomized Phase II Trial of Fulvestrant Plus Everolimus or Placebo in Postmenopausal Women with Hormone ReceptorPositive, Human Epidermal Growth Factor Receptor 2-Negative Metastatic Breast Cancer Resistant to Aromatase Inhibitor Therapy: Results of PrE. J. Clin. Oncol. 2018, 36, 1556-1563. [CrossRef] [PubMed]

89. Royce, M.; Bachelot, T.; Villanueva, C.; Özgüroglu, M.; Azevedo, S.J.; Cruz, F.M.; Debled, M.; Hegg, R.; Toyama, T.; Falkson, C.; et al. Everolimus Plus Endocrine Therapy for Postmenopausal Women with Estrogen Receptor-Positive, Human Epidermal Growth Factor Receptor 2-Negative Advanced Breast Cancer. JAMA Oncol. 2018, 4, 977. [CrossRef]

90. Kikawa, Y.; Kotake, T.; Kajiwara, Y.; Hashimoto, K.; Yamashiro, H.; Ohtani, S.; Takao, S.; Toi, M. Clinical Predictive Factors for the Efficacy of Everolimus in Patients with Hormone Receptor-Positive, HER2-Negative Advanced Breast Cancer: A Multicenter Retrospective Cohort Study in Japan. Breast Cancer Basic Clin. Res. 2019, 13, 117822341882513. [CrossRef]

91. Janowski, B.A.; Corey, D.R. Minireview: Switching on Progesterone Receptor Expression with Duplex RNA. Mol. Endocrinol. 2010, 24, 2243-2252. [CrossRef]

92. Yokota, A.; Hiramoto, M.; Hino, H.; Tokuhisa, M.; Miyazaki, M.; Kazama, H.; Takano, N.; Miyazawa, K. Sequestosome 1 (p62) accumulation in breast cancer cells suppresses progesterone receptor expression via argonaute 2. Biochem. Biophys. Res. Commun. 2020, 531, 256-263. [CrossRef] [PubMed]

93. Conger, A.; Martin, E.; Yan, T.; Rhodes, L.; Hoang, V.; La, J.; Anbalagan, M.; Burks, H.; Rowan, B.; Nephew, K.; et al. Argonaute 2 Expression Correlates with a Luminal B Breast Cancer Subtype and Induces Estrogen Receptor Alpha Isoform Variation. Non Coding RNA 2016, 2, 8. [CrossRef] [PubMed]

94. Nadal, R.; Fernandez, A.; Sanchez-Rovira, P.; Salido, M.; Rodríguez, M.; García-Puche, J.L.; Macià, M.; Corominas, J.M.; DelgadoRodriguez, M.; Gonzalez, L.; et al. Biomarkers characterization of circulating tumour cells in breast cancer patients. Breast Cancer Res. 2012, 14, R71. [CrossRef]

95. Madaras, L.; Balint, N.; Gyorffy, B.; Tokes, A.M.; Barshack, I.; Yosepovich, A.; Friedman, E.; Paluch-Shimon, S.; Zippel, D.; Baghy, K.; et al. BRCA Mutation-Related and Claudin-Low Breast Cancer: Blood Relatives or Stepsisters? Pathobiology 2016, 83, 1-12. [CrossRef] [PubMed]

96. Ahn, S.; Kim, H.J.; Kim, M.; Chung, Y.R.; Kang, E.; Kim, E.-K.; Kim, S.H.; Kim, Y.J.; Kim, J.H.; Kim, I.A.; et al. Negative Conversion of Progesterone Receptor Status after Primary Systemic Therapy Is Associated with Poor Clinical Outcome in Patients with Breast Cancer. Cancer Res. Treat. 2018, 50, 1418-1432. [CrossRef]

97. Viale, G.; Regan, M.M.; Maiorano, E.; Mastropasqua, M.G.; Dell'Orto, P.; Rasmussen, B.B.; Raffoul, J.; Neven, P.; Orosz, Z.; Braye, S.; et al. Prognostic and predictive value of centrally reviewed expression of estrogen and progesterone receptors in a randomized trial comparing letrozole and tamoxifen adjuvant therapy for postmenopausal early breast cancer: BIG 1-98. J. Clin. Oncol. 2007, 25, 3846-3852. [CrossRef]

98. Ellis, M.J.; Tao, Y.; Luo, J.; A’Hern, R.; Evans, D.B.; Bhatnagar, A.S.; Chaudri Ross, H.A.; von Kameke, A.; Miller, W.R.; Smith, I.; et al. Outcome Prediction for Estrogen Receptor-Positive Breast Cancer Based on Postneoadjuvant Endocrine Therapy Tumor Characteristics. JNCI J. Natl. Cancer Inst. 2008, 100, 1380-1388. [CrossRef] [PubMed]

99. Milosevic, J.; Klinge, J.; Borg, A.-L.; Foukakis, T.; Bergh, J.; Tobin, N.P. Clinical instability of breast cancer markers is reflected in long-term in vitro estrogen deprivation studies. BMC Cancer 2013, 13, 473. [CrossRef] [PubMed]

100. Matthews, S.B.; Sartorius, C.A. Steroid Hormone Receptor Positive Breast Cancer Patient-Derived Xenografts. Horm. Cancer 2017, 8, 4-15. [CrossRef]

101. Agrawal, A.; Robertson, J.F.R.; Cheung, K.L.; Gutteridge, E.; Ellis, I.O.; Nicholson, R.I.; Gee, J.M.W. Biological effects of fulvestrant on estrogen receptor positive human breast cancer: Short, medium and long-term effects based on sequential biopsies. Int. J. Cancer 2016, 138, 146-159. [CrossRef] [PubMed]

102. Sabatier, R.; Finetti, P.; Guille, A.; Adelaide, J.; Chaffanet, M.; Viens, P.; Birnbaum, D.; Bertucci, F. Claudin-low breast cancers: Clinical, pathological, molecular and prognostic characterization. Mol. Cancer 2014, 13, 228. [CrossRef] [PubMed]

103. Bjerre, C.; Vinther, L.; Belling, K.C.; Würtz, S.Ø.; Yadav, R.; Lademann, U.; Rigina, O.; Do, K.N.; Ditzel, H.J.; Lykkesfeldt, A.E.; et al. TIMP1 overexpression mediates resistance of MCF-7 human breast cancer cells to fulvestrant and down-regulates progesterone receptor expression. Tumor Biol. 2013, 34, 3839-3851. [CrossRef]

104. Razavi, P.; Chang, M.T.; Xu, G.; Bandlamudi, C.; Ross, D.S.; Vasan, N.; Cai, Y.; Bielski, C.M.; Donoghue, M.T.A.; Jonsson, P.; et al. The Genomic Landscape of Endocrine-Resistant Advanced Breast Cancers. Cancer Cell 2018, 34, 427-438. [CrossRef] [PubMed]

105. NCT04738292 Onapristone and Fulvestrant for ER+ HER2- Metastatic Breast Cancer after Endocrine Therapy and CDK4/6 Inhibitors (The SMILE Study)—Full Text View. Available online: https:/ / clinicaltrials.gov/ct2/show/NCT04738292 (accessed on 8 February 2021). 
106. Ethier, J.L.; Ocaña, A.; Rodríguez Lescure, A.; Ruíz, A.; Alba, E.; Calvo, L.; Ruíz-Borrego, M.; Santaballa, A.; Rodríguez, C.A.; Crespo, C.; et al. Outcomes of single versus double hormone receptor-positive breast cancer. A GEICAM/9906 sub-study. Eur. J. Cancer 2018, 94, 199-205. [CrossRef]

107. Creighton, C.J.; Kent Osborne, C.; van de Vijver, M.J.; Foekens, J.A.; Klijn, J.G.; Horlings, H.M.; Nuyten, D.; Wang, Y.; Zhang, Y.; Chamness, G.C.; et al. Molecular profiles of progesterone receptor loss in human breast tumors. Breast Cancer Res. Treat. 2009, 114, 287-299. [CrossRef]

108. Singhal, H.; Greene, M.E.; Tarulli, G.; Zarnke, A.L.; Bourgo, R.J.; Laine, M.; Chang, Y.-F.; Ma, S.; Dembo, A.G.; Raj, G.V.; et al. Genomic agonism and phenotypic antagonism between estrogen and progesterone receptors in breast cancer. Sci. Adv. 2016, 2, e1501924. [CrossRef]

109. Verde, G.; De Llobet, L.; Wright, R.; Quilez, J.; Peiró, S.; Le Dily, F.; Beato, M. Unliganded Progesterone Receptor Governs Estrogen Receptor Gene Expression by Regulating DNA Methylation in Breast Cancer Cells. Cancers 2018, 10, 371. [CrossRef]

110. Carroll, J.S.; Hickey, T.E.; Tarulli, G.A.; Williams, M.; Tilley, W.D. Deciphering the divergent roles of progestogens in breast cancer. Nat. Rev. Cancer 2017, 17, 54-64. [CrossRef]

111. Karamouzis, M.V.; Papavassiliou, K.A.; Adamopoulos, C.; Papavassiliou, A.G. Targeting Androgen/Estrogen Receptors Crosstalk in Cancer. Trends Cancer 2016, 2, 35-48. [CrossRef]

112. Tagliaferri, B.; Quaquarini, E.; Palumbo, R.; Balletti, E.; Presti, D.; Malovini, A.; Agozzino, M.; Teragni, C.M.; Terzoni, A.; Bernardo, A.; et al. Role of androgen receptor expression in early stage ER+/PgR-/HER2- breast cancer. Ther. Adv. Med. Oncol. 2020, 12, 175883592095835. [CrossRef] [PubMed]

113. Scatena, C.; Scarpitta, R.; Innocenti, L.; Miccoli, M.; Biancotti, R.; Diodati, L.; Ghilli, M.; Naccarato, A.G. Androgen receptor expression inversely correlates with histological grade and $\mathrm{N}$ stage in ER+/PgRlow male breast cancer. Breast Cancer Res. Treat. 2020, 182, 55-65. [CrossRef]

114. Salazar, M.; Lerma-Ortiz, A.; Hooks, G.M.; Ashley, A.K.; Ashley, R.L. Progestin-mediated activation of MAPK and AKT in nuclear progesterone receptor negative breast epithelial cells: The role of membrane progesterone receptors. Gene 2016, 591, 6-13. [CrossRef] [PubMed]

115. Valadez-Cosmes, P.; Vázquez-Martínez, E.R.; Cerbón, M.; Camacho-Arroyo, I. Membrane progesterone receptors in reproduction and cancer. Mol. Cell. Endocrinol. 2016, 434, 166-175. [CrossRef]

116. Dressing, G.E.; Alyea, R.; Pang, Y.; Thomas, P. Membrane Progesterone Receptors (mPRs) Mediate Progestin Induced Antimorbidity in Breast Cancer Cells and Are Expressed in Human Breast Tumors. Horm. Cancer 2012, 3, 101-112. [CrossRef] [PubMed]

117. Wu, X.; Sun, L.; Wang, X.; Su, P.; Li, Z.; Zhang, C.; Wang, Y.; Gao, P.; Ma, R. Breast Cancer Invasion and Metastasis by mPR $\alpha$ Through the PI3K/Akt Signaling Pathway. Pathol. Oncol. Res. 2016, 22, 471-476. [CrossRef]

118. Zhou, L.; Zhou, W.; Zhang, H.; Hu, Y.; Yu, L.; Zhang, Y.; Zhang, Y.; Wang, S.; Wang, P.; Xia, W. Progesterone suppresses triple-negative breast cancer growth and metastasis to the brain via membrane progesterone receptor $\alpha$. Int. J. Mol. Med. 2017, 40, 755-761. [CrossRef] [PubMed]

119. Xie, M.; Zhou, L.; Chen, X.; Gainey, L.O.; Xiao, J.; Nanes, M.S.; Hou, A.; You, S.; Chen, Q. Progesterone and Src Family Inhibitor PP1 Synergistically Inhibit Cell Migration and Invasion of Human Basal Phenotype Breast Cancer Cells. Biomed Res. Int. 2015, 2015, 426429. [CrossRef] [PubMed]

120. Cottu, P.H.; Bonneterre, J.; Varga, A.; Campone, M.; Leary, A.; Floquet, A.; Berton-Rigaud, D.; Sablin, M.-P.; Lesoin, A.; Rezai, K.; et al. Phase I study of onapristone, a type I antiprogestin, in female patients with previously treated recurrent or metastatic progesterone receptor-expressing cancers. PLoS ONE 2018, 13, e0204973. [CrossRef]

121. Truong, T.H.; Dwyer, A.R.; Diep, C.H.; Hu, H.; Hagen, K.M.; Lange, C.A. Phosphorylated Progesterone Receptor Isoforms Mediate Opposing Stem Cell and Proliferative Breast Cancer Cell Fates. Endocrinology 2019, 160, 430-446. [CrossRef] [PubMed]

122. Lamb, C.A.; Fabris, V.T.; Jacobsen, B.M.; Molinolo, A.; Lanari, C. Biological and clinical impact of imbalanced progesterone receptor isoform ratios in breast cancer. Endocr.-Relat. Cancer 2018, 25, R605-R624. [CrossRef] [PubMed]

123. Khan, J.A.; Bellance, C.; Guiochon-Mantel, A.; Lombès, M.; Loosfelt, H. Differential Regulation of Breast Cancer-Associated Genes by Progesterone Receptor Isoforms PRA and PRB in a New Bi-Inducible Breast Cancer Cell Line. PLoS ONE 2012, 7, e45993. [CrossRef] [PubMed]

124. Mote, P.A.; Gompel, A.; Howe, C.; Hilton, H.N.; Sestak, I.; Cuzick, J.; Dowsett, M.; Hugol, D.; Forgez, P.; Byth, K.; et al. Progesterone receptor A predominance is a discriminator of benefit from endocrine therapy in the ATAC trial. Breast Cancer Res. Treat. 2015, 151, 309-318. [CrossRef] [PubMed]

125. Snell, C.E.; Gough, M.; Liu, C.; Middleton, K.; Pyke, C.; Shannon, C.; Woodward, N.; Hickey, T.E.; Armes, J.E.; Tilley, W.D. Improved relapse-free survival on aromatase inhibitors in breast cancer is associated with interaction between oestrogen receptor- $\alpha$ and progesterone receptor-b. Br. J. Cancer 2018, 119, 1316-1325. [CrossRef]

126. Tahiri, A.; Tekpli, X.; Satheesh, S.V.; DeWijn, R.; Lüders, T.; Bukholm, I.R.; Hurtado, A.; Geisler, J.; Kristensen, V.N. Loss of progesterone receptor is associated with distinct tyrosine kinase profiles in breast cancer. Breast Cancer Res. Treat. 2020, 183, 585-598. [CrossRef] [PubMed] 